\title{
DR HERBERT M. EVANS
}

\section{AN INTERVIEW}

A. S. Parkes. Dr Evans, it is very kind of you to talk to us for the Fournal of Reproduction and Fertility, and I hope our conversation won't trouble you too much. May we start at the beginning and ask about your early days?

H. M. Evans. Yes, of course. I was born in 1882, in a Galifornian village with 500 people which now has 70,000 people. My father was Dr G. W. Evans; he was born in Alabama; my mother was Bessy McLean, whose family came from Appomatox, Va., where Lee surrendered to Grant.

$P$. So your father was a medical man.

$E$. Yes, he had a magnificent practice in the town of Modesto and brought most of the babies in Stanislaus County into the world. In addition, he did the first abdominal operations in the Upper San Joaquin Valley.

Miriam Simpson. Your mother's father practised there, too?

$E$. Yes. His name was Samuel Merriwether McLean and he was related to the great Merriwether Lewis, of Lewis and Clarke fame.

$S$. There was a surgeon of that name here in San Francisco, who was he?

$E$. My mother's brother. Robert McLean was the head of surgery and Dean at this school.

$P$. So that your father, maternal grandfather and an uncle all practised medicine in California. With all this medical background, did you go into your father's practice?

$E$. No, my father was heartbroken, but I didn't go into practice with him.

$P$. How did you avoid it?

$E$. It's a long story. My high school principal was an immensely tall Irishman named Thomas Downey, who built up, for a mere high school, a library of repute and took all the standard American journals. His chief attribute, besides these cultural things, wonderful in a high school at that time, was the physical capacity to throw the boys, one after the other, down the stairs.

$P$. And what then?

$E$. My father wanted me to go to the University of California to qualify in medicine. Well, I cannot tell you how much I enjoyed my freshman year. Some of the courses we were offered were not primarily for freshmen, but I would sneak into the classes. I remember that, when Jacques Loeb came to the University, I always sneaked into the back row at his seminar because his fame touched us all.

$P$. What subjects did you take as a freshman?

$E$. I took pre-medical and this embarrassed me because, later, I learned that pre-medical work would savour of medicine and could easily become so specialized that you did not get a general education. And I longed to know a little more.

$P$. So you went through the University of California doing pre-medical? And then? 
$E$. Here, I must digress a bit. It happened that, at about this time, they built a dam to make an irrigation district out of our county where Modesto is, so that the land could grow seven crops of alfalfa a year instead of one crop of wheat, and this changed the whole valley. To celebrate this, they asked President Wheeler to come to make an oration. He was very eloquent, but, more important for me, was the fact that the celebration was attended by Morse Stevens, a professor of history from Cornell. At the celebration he coached Wheeler to persuade my father that I was doing the right thing to get a little better general education. At the end of his speech, Wheeler asked if there is such a man as Dr C. W. Evans in this community? Well, my father was the greatest physician there, and he came up and busted a gut almost and wanted to know why he had been called for. Well, Wheeler said, your son happens to be one of the two student Commencement speakers this year and I would like you to be my guest. I am giving a garden party for a man named Theodore Roosevelt and wish you to come. My father was over-powered, and Wheeler went on to tell him a lot of stuff about what I'd done in the student honour society, which impressed my father very much, and he said: "My boy, come up here." And I came up and he said: "Now look, this monkey business of yours with guineapigs and rabbits seems to have justified itself."

$P$. What is a Commencement speaker?

$E$. Every year there is an important 'Commencement speaker', a great man summoned from Europe or the United States; but two students can also speak 5 minutes each, and they are students deemed to have been the most celebrated in their class. Now, I never deserved that distinction and I don't know how I got it.

$P$. How did you get on?

$E$. I started and President Wheeler said to me: "Now, Mr Evans, you're doing well, but will you go to the edge of the platform and make yourself heard." I never forgot his kindness in saying this, and it will amuse you to hear that my talk was on the importance of biological research for human welfare.

$P$. Is what you said on record?

$E$. I hope not.

$S$. We found a quotation from it the other day.

$P$. Was it a good one?

$S$. Yes, yes! It was in the Berkeley Gazette.

$P$. About dates. You became a freshman in 1900 , so that you made that Commencement speech in 1904? And after that you went to Johns Hopkins School of Medicine at Baltimore.

$E$. Yes, and the minute I got there I regretted to learn that William Osler had gone to be Regius Professor of Medicine at Oxford, befriended by his brother Regius at Cambridge, Glifford Allbutt, who had a grand influence on Osler. When Osler came back after his first year in Oxford and, in the Amphitheatre at Baltimore, gave his famous lecture on Servetus, I was so impressed that I determined forever to take an interest in the history of medicine.

$P$. But Mall was still in Baltimore.

$E$. Oh, yes, very much so, and I began to work with him to learn the tech- 
nique of injection of the vascular system. I became so interested that I cut many classes, because I wanted to study the development of the vascular system in pig embryos. Some of the classes I cut occurred only once a week and struck me as trivial, so that my absence was not likely to disturb anyone. But I got into trouble; I could tell you many funny stories of that situation. Even in my 3rd year medical I cut courses I knew little about, and went to injecting pig embryos to learn something about angiogenesis. As a result, Mall did an extraordinary thing for me in my senior year in medicine-he gave me the opportunity of writing a chapter on the development of the vascular system for the famous 2-volume textbook on 'Human Embryology' by Keibel and Mall. This was a great opportunity for me.

Mall also gave me contacts which made me think about what I had learned. I remember Halsted saying that the removal of a thyroid tumour-a huge struma-had given one of his patients tetany; and I was pretty sure that they had removed more than just thyroid tissue.

$W . R$. Lyons. Your first endocrine interest, then, was in the parathyroid work with Halsted?

$E$. I hadn't thought of it that way, but I'm proud of it. Someone once asked me what was the greatest thing I got out of my 9 years in Baltimore, and I said: "Franklin Payne Mall let me walk across town with him every night and described to me how they were trying to introduce the whole-time system into the clinic. Then, too, I went, at noon, to a German saloon where good beer was served and the men in the various parts of the medical faculty came there, so that I got acquainted with them.

$P$. So you completed medicine at Baltimore in 1908 after 3 years, and stayed on?

$E$. Yes, I stayed on to make a total of 9 years.

$P$. You were in Germany at one time, were you not?

$E$. Yes, during my time in Mall's department he was eager to let me have the opportunity of going to Germany and each year he got me a travelling Fellowship.

$P$. Is this how you started your vital dye work?

$E$. Well, I got into the vital dye work by accident, in the town of Freiburg. E. E. Goldmann, the surgeon, had an experimental laboratory up where the hills began under Salzburg, and I went up there one day and saw white mice that were stained every colour of the rainbow, living and behaving normally; the dyes had come from Ehrlich. I was fascinated and said to myself, "I know a young chemist here named Schulemann, and we'll find out how the animals can tolerate such treatment and whether the capacity of these cotton dyes to act as vital stain is due to chemical constitution or physical action." And so, Schulemann and I spent odd months over several years wandering in 'dyeland'.

$P$. Am I right in thinking that you are the Evans of Evans' Blue? I always thought you must be.

$E$. Yes, Schulemann and I had an amazingly fine time together.

$P$. Apart from the vital dye work for which you went to Germany from time to time, what was your research in Baltimore?

$E$. Mall influenced me, giving me other ideas of the vascular system. I 
reconstructed some human embryos there, but it did not tell you very much about the smallest vessels.

$S$. Dr Evans cut the embryos that were first used at the Carnegie Institution.

$P$. And you reconstructed them?

$E$. A good many of them, yes.

$P$. These were wax models?

$E$. That is so. There was a famous one, 836 , that I'll never forget.

$P$. Reconstructing a human embryo must be quite an operation.

$E$. A wearisome thing to do, compared with making the living embryo pump india ink as though it were blood to show you the multitudinous vascular channels that are always plexusing. And when I found by reconstruction two subclavian arteries instead of one going into the arm bud, Mall said: "Surprising there weren't more." Mall was a great influence as a thinker.

$P$. Altogether, then, you did 9 years in Baltimore; and went back to Berkeley in 1915 , as what?

$E$. As head of the Anatomy Department. I was glad to accept President Wheeler's offer because he said that I could go back East once a year to some national meeting connected with medicine. Many people said to me, "Now remember, the medical faculty doesn't regard anything in the anatomy department as important except gross anatomy"; I said, "Gentlemen, this isn't perhaps the growing part of our subject" and I paid no attention to their advice.

$P$. So you found yourself head of the department of anatomy and determined to do research.

$L$. A point that I wish to ask about is the transition from the vital dye studies to those on reproduction, and I wonder if Dr Evans would say whether or not the atretic follicle study was the first. You were working on the vital dyes at that time?

$E$. Yes, when I returned to California.

$L$. And you found the atretic follicles being organized by macrophages?

$E$. Yes.

$L$. Was that your first physiology of reproduction study?

$E$. Yes, you could call it that.

$P$. You became established in Berkeley in 1916; what happened next?

$E$. It occurred to me that, if one could modify the cellular structure, one would be doing something great. We'd long been used to that kind of study in haematology. I had a group of enthusiastic students who enjoyed working. I instituted a new thing, that, in addition to studying neurology and histology and gross anatomy, they had to pick a problem in which they would have to do something on a living animal and study the outcome; this was their introduction to experimental methods. We had a wonderful rat colony at that time. As a result of having the colony and meeting an amazingly fine man, J. A. Long, who had gotten a Ph.D. at Harvard, I wrote the monograph on The Estrous Cycle in the Rat.

$P$. Was that the only publication of the mass of work described?

L. Yes, except for abstracts published in the Anatomical Record in 1920 and 1921. I think these sets of abstracts ought to be reproduced, because they are forgotten and the monograph is long out of print. 
$P$. This is a fine idea; we will reprint the abstracts in the special number of the $\mathcal{J R F}$.

$E$. Yes, I would like that.

$P$. Goming back to the monograph, it must have taken you a long time to write that.

$E$. It was completed in 1922 . Long had been working quietly on the rat and was using the method of vaginal smears before Stockard and Papanicolaou, but he hadn't published anything on it. After World War I, there was a great influenza epidemic and Long was taken sick. When they propped him up in bed and he felt all right, I sent him the monograph and said: "This is your paper and you are the senior author." And he said: "I expected that, since you put it all together, you would be the senior author." I said: "We have to tell the truth occasionally, Dr Long, this is your work."

$P$. I remember that monograph well, because I went to work at University College in London in 1923 and soon made contact with Jack Drummond, who was Professor of Biochemistry. One of the first things he did when he knew that I was working on rats was to give me the copy of the monograph which you had sent him. I have had it ever since until about 6 months ago when it was stolen or disappeared mysteriously from my office. It was too bad. I had had this copy bound. It was inscribed with Jack Drummond's name in your writing and I had added my own name as coming from Jack Drummond. Now it's gone, but I remember it very well indeed; everybody who works on rats in England refers to it from time to time.

$E$. Well, I owe that whole thing to Joseph Abraham Long. I had sense enough to know it.

$P$. I have a recollection of meeting him when I was here in 1949 but I couldn't swear to it. Was he alive in 1949 ?

$S$. Yes. He died in June 1953.

$P$. In that case, I met him in 1949 , and I am very glad to have done so. $\mathrm{Dr}$ Evans, you must have been phenomenally active in the early 1920s because, if I remember rightly, both your anterior pituitary work and the vitamin $\mathrm{E}$ work date from this time. Certainly, your Harvey Lecture on 'The Function of the Pituitary Gland' was given in 1925 and your massive monograph with Burr on vitamin $\mathrm{E}$ was published in 1927. How did you get into the pituitary work?

$E$. It arose naturally from the work on the oestrous cycle of the rat and was in fact started with Long. Dr Simpson says that I had a notice on my wall saying "Determine the actual conditions which make it possible for hypophysectomized animals to grow normally"; and so on.

$P$. Yes, I remember the 1920 and 1921 abstracts written with Long, but what caused you first to start injecting anterior pituitary preparations?

$E$. I suppose we were influenced by the clinical association between gigantism and pituitary tumours and by Philip Smith's observations on tadpoles. Anyway, the results were spectacular.

We injected normal rats with these crude suspensions-alkaline suspension of fresh pituitary tissue - and made giants out of them, and their oestrous cycles stopped at once. Also we found that these animals not only ate well but had bigger skeletons. I insisted that we had the rare opportunity of finding out what 
dietary and endocrine influences were involved. We also had one of our students study the induction of placentomata in these rats, following Leo Loeb's wonderful work on the guinea-pig.

$P$. How did this tie in with Philip Smith's work? He was in the Anatomy Department, was he not?

$E$. Yes, he had been there for 2 years when I went back to Berkeley in 1915. He had done a very clever thing in Cornell, where he was educated, in studying the normal development of the hypophysis in the frog. He learned that two parts of the pituitary came together from a distance to form a united organ. I said to Smith, "the anterior lobe has surfaced then?" and he said, "yes, and I've found a way of removing it."

$P$. Smith afterwards turned to the rat?

$E$. Yes; his great paper was on hypophysectomy in the rat, by the parapharyngeal route, as he called it. He found the right spot on the base of the cranium to make a circular entry and there was an enormous advantage in the rat, namely, that you need not injure the brain from below because the diaphragma sellae separated the Turk's saddle from the brain. That was an immense advantage, because all the injury in the early hypophysectomies arose from lifting the whole brain to get under it. That was a basic error, and the animals went into a coma at once. Smith's hypophysectomy was a magnificent feat and demonstrated the invariable sequelae of a complete hypophysectomy. He could do fifty or sixty a day and I said to myself, "with ingenuity and chemical brains we can find out if all the different trophic effects are interrelated or if each is an independent entity." Then, later, Smith injected chromic acid to injure that area and duplicated some of the hypothalamic syndromes.

$P$. But later still, when Smith got to hypophysectomizing rats, how did that tie in?

$S$. The earliest work of Smith, both on the frog and the rat, showed that the gonads were smaller after hypophysectomy.

$E$. There was selective atrophy of the so-called target organs: thyroid, gonads, and adrenal cortex. The adrenal cortex change was profound, and one of the fine things that came out of Smith's work. But adrenal cortical physiology was was not very well known then. Later, following work on immature animals with pituitary implants, Smith was able to effect replacement in the hypophysectomized adult.

$L$. At first you didn't test for growth hormone in hypophysectomized animals, did you? You had a 21-day test in normal female rats when I was first there.

$S$. We didn't use the hypophysectomized animals for growth hormone assay until much later. And by that time we had two or three technicians doing it. Pencharz did our first hypophysectomies for routine work.

$P$. This was for FsH assay?

$S$. And ICsH or LH, whichever you like to call it?

$P$. The Icsh terminology arose from the fact you were using the male as a test animal?

$S$. We used the female, too, and studied its interstitial tissue also.

$P$. I see. So ICSH doesn't apply essentially to the male?

S. No. 
$P$. Well, what is the present position? You say that in your opinion FsH is not completely cleaned up yet.

$S$. Nobody, as far as I know, has ever produced a follicle-stimulating hormone that was pure enough. If you gave 20 to 40 times the minimal effective FsH dose you would be able to show interstitial stimulation. Now, these preparations are very potent, down to 5 gamma or less in hypophysectomized animals.

$P$. When did you first get the idea of separating the anterior pituitary hormones?

$S$. The idea of separation came between 1923 and 1925, I think.

$E$. And we set out to separate and purify every one of the six hormones we knew about, and that was a tremendous task. It took over 20 years, but, of course, many other groups were involved, especially with FSH and LH.

$P$. It went on right through the second war.

$E$. That is correct.

$S$. I think it is still going on as far as FsH is concerned. During the whole time, we published again and again that we 'purified' FSH by the criteria we were using at the time.

$P$. This large-scale work, I suppose, was based on material from cattle or pigs.

$E$. And sheep and horses also; but Dr Simpson also did the first primate gonadotrophin work using monkey pituitaries.

$P$. This was much later?

$E$. Oh yes, about' 55 .

$P$. And what do you consider the most interesting biological effect of exogenous gonadotrophins?

$S$. I would say super-ovulation. Unfortunately, that's never been got under control, especially in man. It isn't nice to give birth to five or six human beings at one time.

$P$. No, it isn't nice for a woman to have a litter. And regulation is going to be very difficult. On any dosage of anything, different individuals react differently. Unless they've abolished biological variation, an ovulating dose for one woman would have no effect on another and would be a superovulating dose for a third.

$S$. That is so. And on the subject of individual variation, all our work has been based on large groups of animals.

$P$. What about the gonadotrophins of extra-hypophysial origin. You recognized their difference from pituitary hormones at an early stage?

$S$. Yes. Dr Evans and I were already publishing papers on the difference between chorionic gonadotrophin and follicle-stimulating hormone in the '20s.

$E$. Who discovered pregnant mare serum gonadotrophin?

$L$. Hart and Cole, I think, deserve the credit for that. Zondek thought it was of pituitary origin, at one time.

$E$. I still think that Zondek and his colleagues should have had a Nobel award for their achievements.

$P$. They started up a lot of things, there is no doubt about that.

$E$. Yes, that interview with him that you published was interesting.

$P$. The purpose of an interview is rather different from that of a biography. A biography should be an objective assessment of somebody; an interview is to find out what makes him tick. A man can say things about himself which no 
biographer would want to say. Shall we now discuss the relation of growth hormone to prolactin?

$E$. Dr Lyons, who is working on this subject, will put you in the clear, not only on what we know this minute which is vexatious enough, but with its history.

$L$. But we want you, Dr Evans, to talk about it; that's why I brought up the matter of Dr Riddle this morning.

$E$. That's a spicy thing and I would like this distinguished colleague of ours some time or other to read the passage of arms between me and Oscar Riddle as to whether there is a growth hormone. At one time he thought that with the thyrotrophic and lactogenic hormones, there was no need for growth hormone.

$L$. At that time Riddle was using, on pigeons, the prolactin fractions made for him by Bates; and it's very likely that prolactin as well as growth hormone does have a growth effect on pigeons. When Peter Gauder and John Hollister worked on their Master theses with you, they hypophysectomized pigeons and induced some growth with prolactin, but they also showed that growth hormone, independently of prolactin, caused some growth in such pigeons. They used growth hormone with its prolactin contaminant inactivated.

$P$. That should not be forgotten.

$E$. I think there was some juicy controversy in those days; and so if Alan is looking for juicy things....

$P$. Sparkle, not juice.

$S$. I think we should forget it all.

$E$. I don't like a person who urges only propriety in the world.

$P$. Can I quote you on this: that you 'don't like a person who urges only propriety in the world"?

$E$. I think that we exist only for the pursuit of truth and it is difficult enough to detect truth without wrapping it up. Now, Lyons, will you talk about the human pituitary?

$L$. I could, but it would go on for too long. Briefly, the lactogenic hormone and the growth hormone have not been separated in extracts of human pituitaries.

$E$. Isn't it amazing that growth and lactogenic hormone have not been isolated as distinct entities from human pituitaries?

$L$. I think the reason, Dr Evans, is that some of the chemists attacking this problem are not looking for a separation. Some have said that these activities are in the same molecule. In contrast, our laboratory was brought up on the separation of hormones and I can't quite believe that they aren't different in monkeys and humans.

$P$. You separated them in animal pituitaries?

$L$. Ovine and bovine, particularly. But I have studied human fractions that are very strong in lactogenic and others that are strong in somatotrophic activity. All the clinical evidence militates against any notion that these activities are in one protein from one cell type.

$S$. I'm very pleased to hear you say that.

$L$. In the earlier days of hormonal characterization we had such wonderful collaboration with Dr Evans and Dr Simpson on the assays; and this was an 
example of the biologist and the assayist purifying the hormone in collaboration with the chemist. I happened to get in at both ends; and I appreciate the pituitary chemist's point of view as well as the biologist's. Our laboratory would never have achieved any purifications of pituitary fractions if it had not been for the Evans-Simpson team organizing the assays and biologic characterizations with meticulous care; and most of it involved histological studies of the various target tissues. It took histologists as well as chemists to purify the pituitary hormones.

$S$. That is why anatomists were important in endocrinology in those days.

$L$. Dr Evans doesn't like the term luteotrophic hormone, but he was the one who discovered the effect with Long. It's all in those little Anatomical Record abstracts (1920-21), including the stopping of the oestrous cycle. The picture of the stimulated corpora lutea is in Dr Evans' Harvey Lecture.

$S$. In these early experiments with the injection of alkaline extracts we saw hypertrophy of the mammary apparatus, of course, but we attributed it to the effect of the hormone on the corpora lutea rather than to the effect of a separate hormone.

$P$. That makes two of us.

$E$. The pioneer work of Stricker and Grueter on lactogenic hormone is often overlooked by today's world. They did it in Strasbourg, influenced by Bouin. The Bouin school had an immense influence in this field, didn't it? I went to see Bouin in his old age ... where did he retire to?

$P$. Up into the Ardennes.

$E$. Yes, I went up into those wooded hills just to pay my respects to Bouin.

$P$. I saw him on several different occasions. He was a fine old chap.

$L$. Of course, but again I must inject Dr Evans into the picture because Stricker and Grueter acknowledged, in one of their papers, that Dr Evans had sent the instructions for preparing the hypophysial extract used. Professor Bouin deserves a lot of credit because they were two of his students. Just like you, he had medical students who worked with him for a while. Stricker was an obstetrician; Grueter was a veterinarian and just passing through, so to speak. They reported this elegant finding in 1928 in the Presse Médicale. Dr Evans and Dr Simpson had been working with the rat; otherwise they would have also discovered a direct lactogenic effect of the same hormone that gave them an indirect mammogenic effect via the ovary.

$S$. Yes, we did induce mammary gland development in the presence of the ovaries.

$P$. That was our trouble, too. In London, although working with the rabbit, we were so imbued with the idea that the corpus luteum was doing everything after ovulation, that we didn't bother to take it out.

$L$. And that goes back to Bouin and Fraenkel and some of the other earlier investigators who also worked on the rabbit. The Stricker and Grueter result was a nice example of how the right animal at the right time and a modicum of serendipity provides a person with a nice discovery. The use of spayed animals was the essence of the Stricker and Grueter work. Dr George Corner at Rochester, N.Y., confirmed it. Stricker is still practising in Mulhouse down the 
Rhine from Strasbourg. He presented a very nice prologue at our meeting in 1950 ; and it is published in the report on that Strasbourg Colloquium on Lactation. I asked him at the time whether he had named this hormone and he said, "No, we didn't name it anything. We just had an effect with a crude extract." It wasn't a separate substance as far as they knew, and he didn't know which of the various hormones it would eventually prove to be. At that meeting in Strasbourg he finally used the term 'lactogen' and that's the only time that one of that pair had given the hormone a name. 'Lactogen' is now used sometimes and some journals accept the term LtH as meaning either lactogenic or luteotrophic hormone.

$S$. That really is adding confusion.

$L$. The classic paper showing that lactogenic hormone is luteotrophic in the rat was the long one in 1941 by Evans et al. They used all of the gonadotrophins then available, and only the lactogenic was luteotrophic.

$P$. We still have to talk about the vitamin $\mathrm{E}$ work; we've not heard a word about that yet.

$E$. No. There I made some of my most critical mistakes. I even called it the anti-sterility vitamin. I overlooked the most significant thing about it, that it had nothing specifically important to do with reproduction. It had to do with the voluntary musculature.

$P$. How did you get on to the story?

$E$. American biochemists, and I can name Mendel, Osborn, Sherman and McCollum, who succeeded in showing that the materials grouped under vitamins $A$ and $B$ permitted growth to adulthood in rats. And I asked myself if reproduction might not impose some unique need. This started it; and I found that purified diets to which had been added vitamins A, B and D were not adequate in the maintenance of pregnancy. And then we found that whole grains, like rice and wheat and barley, contained what we called the ' $\mathrm{X}$ ' or anti-sterility factor. So I went to a place where they cracked wheat kernel with big steel rollers into three divisions: the coverings, the centre (endosperm) and the germ. I tried them all; and made extracts; the surface stuff gave us only some faint indication, the endosperm zero, but the germ was the potent stuff. I got nowhere with an aqueous extract, but right away with alcohol and ether found it possible to produce a beautiful brilliant yellow oil. At that time, vitamins $A$ and $D$ were the only fat soluble vitamins known and cod liver oil, enormously high in A and D, did not prevent resorption of the young; in fact, they accentuated the trouble. But one drop of the wheat germ oil for a day maintained pregnancy and it was certain that we had stumbled on a new fat soluble vitamin. You can see how we were led into calling it the anti-sterility vitamin. Then Dr Barnett Sure of Arkansas said: 'Why does Dr Evans keep on calling this vitamin $\mathrm{X}$ ? It deserves the next serial letter. It is not $\mathrm{A}$ or $\mathrm{D}$, because they fed tons of that and got nowhere." I then called it ' $E$ ' with reasonable speed. But the reason that we discovered it, was because the foetuses in utero, at a particular time, failed and got resorbed. And one of your guests tomorrow night, Dr Althausen, studied the histopathological changes in the vitamin E-deficient rats; and showed with beautiful clarity that, primarily, the foetal part of the placenta was in trouble. 
$P$. What part did Dr Burr play in the vitamin E story?

$E$. He was a chemist. And he found that, in wheat germ oil, the active principle was solely in the unsaponifiable portion. I then had to search the world to find anyone who knew anything about the non-saponifiable fats. The next story on $\mathrm{E}$ is that $\mathrm{I}$ discovered that a brilliant man, in Goettingen, named Windhaus, was working on some of the better known vitamins, and knew how to handle non-saponifiable fractions.

$P$. Yes, he was working on $\mathrm{D}$, if $\mathrm{I}$ remember right.

$E$. Yes, on D. Well then, I sent Oliver Emerson and his wife, Gladys, to Windhaus. Windhaus had a brilliant pupil named Butenandt and Butenandt said: "Well, this won't be too difficult," and he made the contribution that led to the differentiation of alpha, beta and gamma tocopherols. Thus, it may be said that the study of the chemistry of vitamin $E$ culminated in the establishment of the precise graphic formula of the alpha, beta and gamma tocopherol, an achievement which, it has to be confessed, was almost simultaneously accomplished by Karrer of Zurich, John of Goettingen, and L. I. Smith of Minnesota. The four papers appeared virtually together. I feel, though, that this work rested on the isolation of what they called the three tocopherols by Emerson and Evans and was foreshadowed by the remarkable prediction of its formula by Fernholz of Merck Laboratory.

$P$. How was the word tocopherol evolved?

$E$. I had a luncheon in Berkeley with a professor of Greek, by the name of Calhoun. And I said: "I want a name for a vitamin." He said, "What does it do?" I said, "Here is an animal that can't maintain its young; and you give this to them in traces and then in time it enables them to do so." Calhoun said, "Well, offspring in Greek is 'tokos' and 'phero' means to bear." So it is: 'tokos' and 'phero'. And so Calhoun's 'tocopherol' was coined for ' $E$.'

$P$. Well! Did you get into the story of the effects of vitamin E deficiency in the male?

$E$. Yes, but a little belatedly. We couldn't cure them after they had gotten paralysed. When we got the male into trouble we could not resuscitate the testes, because the deficiency had involved a generation of spermatogenesis. But we could prevent it by mixing the pure diet with various kinds of natural foodstuff.

$P$. And what about the muscular effect?

$E$. I thought it was neural because amyotrophic lateral sclerosis was in my mind.

$P$. Was that in adults or in young rats?

$E$. In adults, unfortunately. That led me astray.

$S$. But you had paralysis in the newborn, too.

$E$. Ah, but that is different. We knew, and this was due to Dr Simpson's work with me, what the minimal dose was to ensure a birth, and so we got paralysis of the suckling young when the mothers had had the bare minimum dose to get them born. And that's the explanation of the paralysis of the suckling young.

$S$. What year was that?

$E$. Evans with Burr first reported the disturbance of neuromuscular physiology 
in a paper called 'Development of Paralysis in the Suckling Young of Mothers Deprived of E', published in 1928. In that year also, I reported that $\mathbf{E}$ was important in causing more body growth than you could possibly have with the constituents that were thought at that time to do everything else.

$P$. There were other developments of one sort and another in the $\mathbf{E}$ work?

$E$. Yes. To H. A. Mattill of lowa belongs the credit of establishing the basic anti-oxidant effect, of vitamin $\mathrm{E}$. With Cornish, the use of long fractionating columns was adapted then to the extraction of E. Evans with Bishop, at the same time, continued the study of the biological action of this vitamin. Proof of the power of the body readily to store the substance was obtained; and of interest, in retrospect, is the relatively high content of ' $E$ ' in striated musculature. An important review of the early studies on the relation between fertility and nutrition was then given at the Mayo Foundation in '24. Finally, monographic treatment of all our early biological and chemical work was published in 1927 by Evans, Burr \& Althausen. Here are reported our first efforts to analyse, histologically, the cause of foetal death, then a still unsolved problem.

$P$. Were there any clinical developments of this work?

$E$. The discovery of paralysis of the suckling young from mothers held on food so low in $\mathbf{E}$ that gestation and parturition were only just possible, led some investigators to entertain the concept that neuromuscular disorders, in man, might have a similar origin and to attempt a cure of such maladies, especially of amyotrophic lateral sclerosis, with vitamin $\mathrm{E}$. Inasmuch as the original work on paralysis from low $\mathbf{E}$ showed it to be prophylactically prevented by enough $\mathrm{E}$, but when once established, never curable by this material, I had little expectation that it could play the dramatic therapeutic role widely claimed for it.

$P$. If I remember rightly, you had other excursions into nutrition.

$E$. Yes. At the initiation of the nutritional studies, Scott Bishop and I made another important observation on the role of food factors in the reproductive mechanism. We found that with low A, you had a cornification of the mucosae in the body.

$P$. And what next?

$E$. Another observation was made in the Berkeley laboratory in '27 by Burr and me; we called it a new dietary deficiency with highly purified diet. The report on this work was the first announcement of the need for unsaturated fatty acids and we called them, unfortunately, a flock of 'F's'. This problem was carried further by Burr and, later, studied carefully by Evans and Lepkovsky. The first contribution to the physiology of what, at that time, people were calling the $B$ complex came from my laboratory, on the need of these substances in lactation. In this paper, the greatly increased need of B in lactation was first reported.

$P$. Let me ask you, now, about your work on the oestrous cycle of the dog in which H. H. Cole was involved.

$E$. Yes, he reminded me of it last night. The main conclusion was that the pro-oestrous bleeding of the bitch is not analogous to menstruation in primates, including man, and should be carefully distinguished from it.

$P$. What was the date of this? Marshall, to the very end, was confused about the two phenomena. 
$S$. Dr Evans presented the abstracts on the oestrous cycle of the dog in 1927 and the memoir was published in 1928.

$E$. Yes, we obtained the dogs from the Pound. To the old women, who were officers of the Society for the Prevention of Cruelty to Animals, I said, "Now, ladies, we want to study these animals in order to understand the menstrual cycle in women," and that made them help me.

$P$. That was a good approach.

$L$. This reminds me of the other story about the woman who didn't like to see you and Long go after the garbage for the rats. When the colony was started you weren't able to buy food for the rats. Didn't you have to go and gather it from the boarding houses?

$E$. Yes, that's where I went for my best food and, on Sunday morning when I'd meet President Wheeler with his top hat on going to church, I would be carrying a bucket of selected table scraps.

$S$. And then you became the garbage king.

$E$. Then I became the garbage king of Berkeley. One of the boarding house women asked me, "Aren't you ashamed of yourself; a grown man like you getting scraps for varmints."

$P$. Where did Dr Scott Bishop come into all this?

$E$. I brought her and George Corner from Baltimore; her name was Katherine Scott and she later married a man named Bishop; a very fine character, whom I got to like very much. She collaborated extensively on the vital dye studies and on vitamin $\mathbf{E}$ research.

$P$. Was George Corner here for a time?

$E$. Yes, for 5 or 6 years.

$P$. What date was this?

S. I studied topographical anatomy with him in '18, when he'd been here about 4 years. He might have stayed a year or two after that. He then went back to Baltimore, and later when Rochester's School of Medicine opened he became the first Professor of Anatomy.

$L$. Dr Corner's 'Oestrous Cycle of the Sow' came out of this Department and a local slaughterhouse. It was a Carnegie Institute Contribution to Embryology monograph.

$P$. We were talking about Marshall a little earlier. Did he ever visit you here?

$E$. No, I regretted it.

$P$. You met Marshall, of course, somewhere or other?

$E$. Yes, I met him at Christ's College in Cambridge.

$P$. He used to spend part of his vacations in his cottage on some small river in Norfolk. I never went there, did you?

$E$. Yes, I went there. I was devoted to Marshall and I've felt very honoured by the award of the Marshall medal. His book, the first to be devoted to the Physiology of Reproduction, was a masterpiece.

$P$. Did he send you any research students?

$E$. Yes, Catchpole and Asdell came from Marshall.

$L$. Catchpole worked on pregnant mare gonadotrophin. At Rowell's horse ranch he was up to his knees in blood and everything else for a year; and he used about 10,000 rats for his Ph.D. thesis work. Dr Evans was at the Rocke- 
feller Institute then, and left us with plenty of rats. While speaking of Marshall, wasn't it he who wanted "results he could see?" Was that not in the interview with John Hammond?

$E$. That is in the Hammond interview, yes; Marshall said, "If it's a good result you can see it", and John Hammond elaborated the idea and said "only marginal results need statistics and marginal results are no use in practical animal husbandry."

$P$. I'd like to hear, if I may, about your work with Swezy on the human chromosomes.

$E$. Yes, we made a serious mistake. I think when Olive Swezy and I announced 48 instead of 46, we were counting the long tails of a particular pair of human chromosomes. There was a constriction in a chromosome and Olive Swezy counted them as separate chromosomes and made 48 . We worked with sections in those days, not the smear technique.

$P$. How did you get the material for this work?

$E$. Mostly from St Quentin prison after hangings, to get it quickly; but before the physician held his hand up that the heart had stopped beating, many minutes had gone by and the tissue was deteriorating rapidly; it took us a long while to realize we must get it at the operating table and immediately plunge it into the fixative.

$P$. Dr Evans, we're getting near to the end of our sessions. May I ask some $\$ 64,000$ questions?

$E$. Of course.

$P$. Here's the first. I see from your bibliography that you have been associated with about 700 published papers.

$E$. That might be true. Over 600 , anyway.

$P$. Which is just about twice as many as I have been associated with. I mention this not because I'm competing but because, looking back over the list, I reckon that perhaps about one-third of my original papers have made some impact on the subject, perhaps one-third. On this kind of assessment, how do you think you score?

$E$. If you investigate my scientific life, you will find that $I$ have appropriated from colleagues and pupils $100 \%$ of my achievements.

$P$. That doesn't exactly answer my question, but it leads me to my next one. We were talking yesterday about research students and how different people handle them in different ways. I remember talking to John Hammond about this several years ago. He said emphatically that he threw them in at the deep end, and if they swam that was fine and if they sank, well, that at least was diagnostic. If I understood correctly, from what you've said, you gave them a great deal of attention but otherwise a fairly free hand.

$E$. Correct. And I used the expression: "I neglected them soundly."

$S$. May I add to that, Dr Evans? If students came to us to work, we were apt to neglect them until we saw they wanted to accomplish something and then we pushed them. We pushed them very hard, often far harder than we should have. So you can't say you neglected them.

$P$. No, I understand that.

$E$. Let me ask a question. How did you handle research students, Alan? 
$P$. I tried to provoke them.

$E$. You can use an extreme term like that? You irritated them somewhat?

$P$. Yes. Of course I'm out of it now, but previously every time anybody wanted some piece of elaborate apparatus, I used to say, "You ought to be using your brains, not apparatus." There is too much tendency to rely on elaborate instrumentation these days.

$E$. Unless you want a thing of enormous cost, our research board thinks your work is worthless. to?

$P$. Now, the next question. What made you do research? Why did you want

$E$. When someone wants to know why alpinists climb a mountain the answer is: "because the mountain is there."

$P$. But I imagine you are one of these people who, at some stage, realized you'd not be happy doing anything else, that you had to do research or bust.

$E$. Yes, I suppose that is so. But I've had some shocks. My teacher, Mall, who was trained by His and Ludwig in Leipzig, said that a fundamental philosophy in all biological research was the Fragestellung. My God, I didn't even know what the Fragestellung was, but Mall explained, "you have to know what to ask of Madame Nature, don't ask 'why', but 'how'."

$P$. I agree with that entirely. I've always said that a scientist is entitled to ask 'how' but not 'why'.

$E$. Of course! 'Why' is an indisputable question that only the Lord can answer.

$P$. Yes, you've got to go to Church to ask that, not to a laboratory.

E. Great.

$P$. Anyway, you're one of these people who simply must investigate something and that if you were cast on a desert island, as soon as you got a roof over your head or even before, you'd start investigating how things grew.

$S$. As a matter of fact, Dr Evans is quite a botanist.

$E$. When I joined the Sierra Club I carried a plant press, and collected on the timberline. This gave me great zest and even now I can recognize a good many of the landmarks. I was impressed by C. Hart Merriam's work.

$P$. Did this interest derive from the palaeontology?

$E$. It had something to do with it. Palaeontology came out of my admiration for Zittel at Munich because John C. Merriam was a pupil of Zittel.

$P$. If I remember correctly, I once introduced you at a meeting of the Royal Society of Medicine in London?

$E$. Yes, you did.

$P$. I referred to the fact that your first paper, 'A new cestracient spine from the lower Triassic of Idaho' published in 1904, was on vertebrate palaeontology, which surprised them all.

$E$. I remember that well. I was very flattered. At the time of that study Merriam said, "I know you were bored by that work, you're only interested in higher vertebrates." "Oh, no," I said, "I might learn something from all".

$P$. This explains your palaeontology. How did you become interested in the history of science?

$E$. Osler gave me a taste for the history of biology and then, much more 
important, for the history of science. I founded a little club in Berkeley in 1933, called the History of Science Dinner Club, and when Sarton came out here and Charles Singer, a still greater influence, they were surprised that we did that. And Mrs Singer, Dorothea Singer, taught palaeography, and she had two students. Those were great influences in Berkeley, Sarton and Charles Singer.

$P$. Charles Singer was at University College in my days there.

$E$. His was a most important approach. The great immortal Goethe said, "The History of a subject is the subject." You know, he is so idolized by the Germans that when I was visiting Heidelberg I saw on a post by a little hotel on the Neckar the following inscription: Hier hat Goethe beinähe übernachtet, (Here Goethe almost stayed a night), but the Hotel was full. They still put this on a post. That's idolatry, isn't it?

$P$. Yes, that's a new one on me. It's a nice story.

$E$. Some good things came out of Germany and some hellish bad ones, such as when the Geheimrat tells you to get the hell busy and do his problems.

$P$. Coming back to the history of science, which of the many lines of research with which you have been associated do you think has made the most important contribution to the history of science? Which will be most remembered 100 years from now?

$E$. You'll have to ask the Man at the Holy Gate when you get there. In the meantime, I'd say the epochal thing is physics.

$P$. I mean, of the lines of work with which you yourself have been associated. The vitamin E, the pituitary story, and so forth. Which, in the end, will prove to have been the most important contribution to science? They may all be important but they can't all be the most important. What do you think?

$E$. I think endocrinology will give a good account of itself.

$P$. You mean the pituitary work?

$E$. Well, someone in a silly way said that the pituitary was the leader of the endocrine orchestra.

L. On that same occasion Time magazine dubbed Dr Evans, "The premier antepituitarian."

$P$. What about the future of reproductive endocrinology? Where is that going?

$E$. In your talk last night you let no significant thing go unmentioned and I will answer in your own words that what we know for a few creatures to which we have become habituated may be a very poor example of what we have to learn. Your talk was to me one of the best things I have listened to in many a year.

$P$. That's nice of you to say so.

$E$. No, I mean it, and many others were open-eyed as they left with their mouths hanging open.

$P$. Perhaps they were thirsty. Next question, you referred earlier to having technicians in at your discussions-was that usual with your lab?

$E$. Yes. You can't tell who is going to suggest something useful. You can't classify people as scientists and technicians. It is very difficult to pass judgment quickly on any one. We got a great deal out of people who advanced from one stage to the next and then perhaps to medicine. 
$P$. In England, we have a much clearer division between graduate staff and technicians. The technicians have their own salary scale, their own organization, their own qualifications, and comparatively rarely pass to the graduate staff.

Dr Evans, this brings me to the end of my questions. What you have told us will be of very great interest to the readers of the Fournal of Reproduction and Fertility.

$E$. I told my wife that it would be a hard ordeal. Not only has it not been that, I've enjoyed it.

$P$. I'm delighted to hear that. It's been what I understand anatomists call 'blunt dissection', but I hope it hasn't been too blunt or too much like dissection. Thank you, Dr Evans, for your patience and good humour during these enjoyable sessions, and thank you, Dr Lyons and Dr Simpson, for your help.

\section{HERBERT McLEAN EVANS}

\section{Curriculum Vitae}

Evans, Herbert McLean: Born at Modesto, California, September 23, 1882; B.S., University of California, 1904; M.D., Johns Hopkins University, 1908; M.D. (honoris causa), Albert Ludwigs-Universität Freiburg i. Br., 1930, and Universidad Catolica de Chile, 1941; Docteur Honoris Causa, Universidad Nacional de San Marcos de Lima, 1941, University of Paris (Sorbonne), 1946; Sc.D., University of Birmingham, 1950; Docteur Honoris Causa, Universidad Central del Ecuador, 1954; LL.D., University of California, 1955; Docteur es Sciences, Honoris Gausa, Université de Génève, 1956; Sc.D., Johns Hopkins University, 1957; Sc.D., University of Bridgeport, 1960.

Assistant, Instructor, Associate, and Associate Professor of Anatomy, Johns Hopkins University, 1908-15; Research Associate, Carnegie Institution of Washington, 1913-15; Professor of Anatomy, University of California, 1915-52; Professor Emeritus, 1952- ; Herzstein Professor of Biology and Director of the Institute of Experimental Biology, University of California, 1930-52; Professor Emeritus and Director Emeritus, 1952- ; Honorary Professor, Facultad de Biologia y Ciencias Medicas, Universidad de Chile, and Facultad de Ciencias Medicas, Universidad Central del Ecuador, 1941. Awarded John Scott Medal, 1928. Awarded gold medal (first award) for Scientific Exhibit, American Medical Association, San Francisco, 1946. Awarded Banting Medal, 1949, and Squibb Award, Association for the Study of Internal Secretions, 1949. Charles Mickle Fellow, University of Toronto, 1949. Passano Award, Baltimore, 1952. Fellow of the Center for Advanced Study, Wesleyan University, 1959-60.

Fellow, American Academy of Arts and Sciences; Member, National Academy of Sciences; Member, Kaiserliche Leopoldinisch-Carolinische Deutsche Akademie der Naturforscher; Member, Societas Regia Medicorum Budapestinensis; Honorary Foreign Member, Academia Nacional de Medicina de Buenos Aires; Honorary Member, Sociedad Medica de Santiago (Chile); Foreign 
Member, Royal Society of London; Foreign Member, Royal Swedish Academy of Sciences, Stockholm; Member, American Association of Anatomists (President, 1930-32); Member, American Physiological Society; Member, Society for Experimental Biology and Medicine; Member, Phi Beta Kappa; Sigma Xi; Alpha Delta Phi; Alpha Omega Alpha; Nu Sigma Nu. Member, History of Science Society. Corresponding Member, Sociedad Argentina de Biologia. Honorary Member, Sociedad de Biologia de Santiago de Chile, 1942. Foreign Corresponding Member, Académie Nationale de Médecine, Paris, 1954.

Faculty Research Lecturer, University of California, 1925; Bacon Lecturer, University of Illinois, 1931; Herzstein Lecturer, Stanford University and University of California, 1934; Beaumont Lecturer, Wayne County Medical Society, Detroit, 1937; Jackson Lecturer, University of Minnesota, 1937; William Henry Welch Lecturer, Mount Sinai Hospital, New York, 1939; Jones Lecturer, University of Oregon, 1940; Messenger Lecturer, Cornell University, 1942; Mellon Lecturer, University of Pittsburgh, 1942; National Sigma Xi Lecturer, 1942; Guiteras Lecturer, American Urological Association, New York, 1942; Porter Lecturer, University of Kansas, 1943; Vanuxem Lecturer, Princeton University, 1946; Ludwig Hektoen Lecturer, Frank Billings Foundation, Institute of Medicine of Chicago, 1947; William E. Lower Lecturer, Gleveland Academy of Medicine, 1947; Eastman Memorial Lecturer, University of Rochester, 1947; Banting Memorial Lecturer, American Diabetes Association, 1949; William Withering Lecturer, University of Birmingham, England, 1950; MacArthur Lecturer, University of Edinburgh, 1950; WalkerAmes Lecturer, University of Washington, 1954; Faculty Research Lecturer, University of California School of Medicine, San Francisco, 1959-60.

\section{SELECTED PUBLICATIONS}

\section{7}

The parathyroid glandules. Their blood supply, and their preservation in operation upon the thyroid gland. (with W. S. Halsted.) Ann. Surg. 46, 489.

1916

On the behavior of the mammalian ovary and especially of the atretic follicle towards vital stains of the acid azo group. Proc. Soc. exp. Biol. Med. 13, 80.

1922

The rhythm of gonadal function with special reference to the relations between uterus and ovary. In: Endocrinology and Metabolism. 2, 572. Eds. L. F. Barker, R. G. Hoskins and H. O. Mosenthal. New York, London.

On the relations between fertility and nutrition. I. The ovulation rhythm in the rat on a standard nutritional regime. (with Katherine S. Bishop.) f. metabol. Res. 1, 319.

On the relations between fertility and nutrition. II. The ovulation rhythm in the rat on inadequate nutritional regimes. (with Katherine S. Bishop.) F. metabol. Res. 1, 335.

Characteristic effects upon growth, oestrus and ovulation induced by the intraperitoneal administration of fresh anterior hypophyseal substance. (with J. A. Long.) Proc. natn. Acad. Sci. U.S.A. 8, 38.

The oestrous cycle in the rat and its associated phenomena. (with J. A. Long.) Mem. Univ. Calif. 6, 148.

On the existence of a hitherto unrecognized dietary factor essential for reproduction. (with Katherine S. Bishop.) Science, N.Y. 56, 650.

On the relations between fertility and nutrition. III. The normal reproductive performance of the rat, (with Katherine S. Bishop.) 7. metabol. Res. 3, 201. 
On the relations between fertility and nutrition. IV. The production of sterility with nutritional regimes adequate for growth and its cure with other foodstuffs. (with Katherine S. Bishop.) 7. metabol. Res. 3, 233.

1925

The function of the anterior hypophysis. Harvey Lect. (1923-1924) 19, 212.

1927

The synthesis of vitamin E by plants grown in culture solutions. (with D. R. Hoagland.) Am. F. Physiol. $80,702$.

Vitamin E: the ineffectiveness of curative dosage when mixed with diets containing high proportions of certain fats. (with G. O. Burr.) 7. Am. med. Ass. 88, 1462.

A new dietary deficiency produced with highly purified diets. (with G. O. Burr.) 7. biol. Chem. 74, 72.

The antisterility vitamin: fat soluble E. (with G. O. Burr \& T. L. Althausen.) Mem. Univ. Calif. 8, 176.

1928

Development of paralysis in the suckling young of mothers deprived of vitamin E. (with G. O. Burr.) 7. biol. Chem. 76, 273.

A new dietary deficiency with highly purified diets. III. The beneficial effect of fat in the diet. (with G. O. Burr.) Proc. Soc. exp. Biol. Med. 25, 390.

The effects of inadequate vitamin $A$ on the sexual physiology of the female. $\mathcal{F}$. biol. Chem. 77, 651 .

Spontaneous deciduomata in pseudopregnancy with low vitamin E. Am. F. Physiol. 85, 149.

Sterility in inbred rats. Am. F. Physiol. 85, 154.

The effect of inadequate vitamin B upon sexual physiology in the male. 7 . Nutr. 1, 1.

Relation of vitamin E to growth and vigor. F. Nutr. 1, 23.

A sex difference in chromosome lengths in the mammalia. (with Olive Swezy.) Genetics, Princeton, 13, 532.

Antagonism of growth and sex hormones of the anterior hypophysis. (with Miriam E. Simpson.) 7. Am. med. Ass. 91, 1337.

1929

Impairment of the birth mechanism due to hormones from the anterior hypophysis. (with Miriam E. Simpson.) Proc. Soc. exp. Biol. Med. 26, 595.

Stimulation of placentoma reaction in virginal endometrium by treatment with anterior hypophyseal hormone. (with Miriam E. Simpson.) Proc. Soc. exp. Biol. Med. 26, 597.

Hyperplasia of mammary apparatus in precocious maturity induced by anterior hypophyseal hormone. (with Miriam E. Simpson.) Proc. Soc. exp. Biol. Med. 26, 597.

Hyperplasia of mammary apparatus of adult virginal females induced by anterior hypophyseal hormones. (with Miriam E. Simpson.) Proc. Soc. exp. Biol. Med. 26, 598.

A comparison of anterior hypophyseal implants from normal and gonadectomized animals with reference to their capacity to stimulate the immature ovary. (with Miriam E. Simpson.) Am. J. Physiol. 89, 371.

A sex difference in the hormone content of the anterior hypophysis of the rat. (with Miriam E. Simpson.) Am. 7. Physiol. 89, 375.

The effect of pregnancy on the anterior hypophysis of the rat and cow as judged by the capacity of implants to produce precocious maturity. (with Miriam E. Simpson.) Am. F. Physiol. 89, 379.

A comparison of the ovarian changes produced in immature animals by implants of hypophyseal tissue and hormone from the urine of pregnant women. (with Miriam E. Simpson.) Am. F. Physiol. 89, 381 .

The chromosomes in man: sex and somatic. (with Olive Swezy.) Mem. Univ. Calif. 9, 1.

Maturation of human embryonic ova. (with Olive Swezy.) Proc. Soc. exp. Biol. Med. 27, 10.

Ovogenesis in the mammalia. (with Olive Swezy.) Proc. Soc. exp. Biol. Med. 27, 11.

Potent, sterile and low-protein extracts of the growth hormone from the anterior hypothesis. (with R.E. Cornish \& Miriam E. Simpson.) Proc. Soc. exp. Biol. Med. 27, 101.

1930

Ovarian changes during pregnancy in the rat. (with Olive Swezy.) Science, N.r. 71, 46.

Aschheim-Zondek test for pregnancy-its present status. (with Miriam E. Simpson.) Calif. west. Med. 32, 145.

The human ovarian germ cells. (with Olive Swezy.) J. Morphol. 49, 543.

1931

The uterus-ovary relationship and its bearing on the time of ovulation in primates. (with Olive Swezy.) Am. J. Physiol. 96, 628. 
The effects of hypophyseal hormones on ovogenesis in the foetal ovary. (with Olive Swezy.) Anat. Rec. $50,189$.

Effect of adrenalectomy on the testes of the rat. (with S. C. Freed \& B. Brownfield.) Proc. Soc. exp. Biol. Med. 29, 1.

Hormones of the anterior hypophysis. (with Miriam E. Simpson.) Am. F. Physiol. 98, 511.

An introduction to the study of the oestrous cycle in the dog. (with H. H. Cole.) Mem. Univ. Calif. 9, 65, Ovogenesis and the normal follicular cycle in adult mammalia. (with Olive Swezy.) Mem. Univ. Calif. 9, 119.

1932

Testicular degeneration due to inadequate vitamin $\mathrm{A}$ in cases where $\mathrm{E}$ is adequate. Am. F. Physiol.99, 477.

Relation of prolan to the anterior hypophyseal hormones. (with K. Meyer \& Miriam E. Simpson.) Am. F. Physiol. 100, 141.

Relative ineffectiveness of prolan in hypophysectomized animals. (with F. L. Reichert, R. I. Pencharz, Miriam E. Simpson \& K. Meyer.) Am. F. Physiol. 100, 157.

Disturbance of carbohydrate metabolism in normal dogs injected with the hypophyseal growth hormone. (with K. Meyer, Miriam E. Simpson \& F. L. Reichert.) Proc. Soc. exp. Biol. Med. 29, 857.

Cure of the cachexia following hypophysectomy by administration of the growth hormone and its relation to the resulting adreno-cortical repair. (with $\mathrm{K}$. Meyer, R. Pencharz \& Miriam E. Simpson.) Science, N.Y. 75, 442.

Vitamin E. J. Am. med. Ass. 99, 469.

\section{3}

The hypophyseal substance giving increased gonadotropic effects when combined with prolan. (with Miriam E. Simpson \& P. R. Austin.) 7. exp. Med. 57, 897.

The growth and gonad-stimulating hormones of the anterior hypophysis. (with K. Meyer, Miriam E. Simpson, A. J. Szarka, R. I. Pencharz, R. E. Cornish \& F. L. Reichert.) Mem. Univ. Calif. 11, 446.

Present position of our knowledge of anterior pituitary function. 7. Am. med. Ass. 101, 425.

Further studies on the hypophyseal substance giving increased gonadotropic effects when combined with prolan. (with Miriam E. Simpson \& P. R. Austin.) J. exp. Med. 58, 545.

The recognition and comparison of prolan and prolan-like substances. (with Miriam E. Simpson \& $\mathrm{P}$. R. Austin.) 7. exp. Med. 58, 561.

Concentration of the gonadotropic hormone in pregnant mare's serum. (with E. L. Gustus \& Miriam E. Simpson.) 7. exp. Med. 58, 569.

The female sex hormones: the present status of our knowledge of anterior pituitary function. Trans. Congr. Am. Physns Surg. 15, 25.

1934

Hypertrophy of the female pituitary following injection of gonadotropic hormone. (with Miriam E. Simpson \& M. McQueen-Williams.) Univ. Calif. Publs. Anat. 1, 161.

Vital need of the body for certain unsaturated fatty acids. IV. Reproduction and lactation upon fat-free diets. (with S. Lepkovsky \& Elizabeth A. Murphy.) 7. biol. Chem. 106, 431.

Vital need of the body for certain unsaturated fatty acids. V. Reproduction and lactation upon diets containing saturated fatty acids as their sole source of energy. (with S. Lepkovsky \& Elizabeth A. Murphy.) 7. biol. Chem. 106, 441.

Vital need of the body for certain unsaturated fatty acids. VI. Male sterility on fat-free diets. (with S. Lepkovsky \& Elizabeth A. Murphy.) f. biol. Chem. 106, 445.

The repair of the reproductive system of hypophysectomized female rats by combinations of an hypophyseal extract (synergist) with pregnancy-prolan. (with R. I. Pencharz \& Miriam E. Simpson.) Endocrinology, 18,601.

Maintenance and repair of the reproductive system of hypophysectomized male rats by hypophyseal synergist, pregnancy-prolan and combinations thereof. (with R. I. Pencharz \& Miriam E. Simpson.) Endocrinology, 18, 617.

\section{5}

Clinical manifestations of dysfunction of the anterior pituitary. F. Am. med. Ass. 104, 464.

Production of superovulation in normal immature rats by injection of the principle in menopause urine. (with Miriam E. Simpson.) Proc. Soc. exp. Biol. Med. 32, 1046.

Synergism or augmentation produced by the addition of an hypophysial synergist to menopause or castration urine. (with Miriam E. Simpson.) Proc. Soc. exp. Biol. Med. 32, 1047.

A sensitive biological test for menopause or castration prolan. (with Miriam E. Simpson.) Proc. Soc. exp. Biol. Med. 32, 1048. 
Gonadotropic effects in hypophysectomized female rats of implants of pituitaries from castrated males.

(with Miriam E. Simpson \& R. I. Pencharz.) Proc. Soc. exp. Biol. Med. 32, 1048.

The growth hormone of the anterior pituitary. J. Am. med. Ass. 104, 1232.

On the conditions necessary for the continuous growth of hypophysectomized animals. (with R. I. Pencharz \& Miriam E. Simpson.) Endocrinology, 19, 509.

\section{6}

The isolation from wheat germ oil of an alcohol, $\alpha$-tocopherol, having the properties of vitamin $\mathrm{E}$. (with O. H. Emerson \& Gladys A. Emerson.) J. biol. Chem. 113, 319.

Gonadotropic hormones ... I. West. 7. Surg. Obstet. Gynec. 44, 175.

Gonadotropic hormones ... II. West. F. Surg. Obstet. Gynec. 44, 199.

Hypophyseal infantilism: treatment with an anterior hypophyseal extract; final report. (with E. Kost Shelton \& L. A. Cavanaugh.) Am. 7. Dis. Child. 52, 100.

On the separation and properties of the antagonist, a pituitary substance inhibiting ovarian responses to gonadotropic hormones. (with K. Korpi, R. I. Pencharz \& Miriam E. Simpson.) Univ. Calif. Publs Anat. 1, 237.

On the separation of the interstitial cell-stimulating, luteinizing and follicle-stimulating fractions in the anterior pituitary gonadotropic complex. (with K. Korpi, Miriam E. Simpson, R. I. Pencharz \& D. H. Wonder.) Univ. Calif. Publs Anat. 1, 255.

1937

Gonadotropic hormone in the blood and urine of early pregnancy; the normal occurrence of transient extremely high levels. (with Clara L. Kohls \& D. H. Wonder.) J. Am. med. Ass. 108, 287.

The chemistry of vitamin E: tocopherols from various sources. (with $\mathrm{O}$. H. Emerson, Gladys A. Emerson \& Ali Mohammad.) 7. biol. Chem. 122, 99.

An anterior pituitary gonadotropic fraction (ICSH) specifically stimulating the interstitial tissue of testis and ovary. (with Miriam E. Simpson \& R. I. Pencharz.) Cold Spring Harb. Symp. quant. Biol. 5, 229.

1938

The purification of the anterior pituitary growth hormone by fractionation with ammonium sulfate. (with Nao Uyei, Q.R. Bartz \& Miriam E. Simpson.) Endocrinology, 22, 483.

Degeneration of cross striated musculature in vitamin E-low rats. (with Gladys A. Emerson \& I. R. Telford.) Proc. Soc. exp. Biol. Med. 38, 625.

Work performance of hypophysectomized rats treated with anterior pituitary extracts. (with D. J. Ingle \& H. D. Moon.) Am. F. Physiol. 123, 620.

The hypophyseal growth hormone-its separation from the hormones stimulating the thyroid, gonads, adrenal cortex and mammary glands. Res. Publs Ass. Res. nerv. ment. Dis. (Proc., 1936) 17, 175.

\section{9}

Endocrine glands: gonads, pituitary, and adrenals. A. Rev. Physiol. 1, 577.

Characterization of gonadotropic hormones of the hypophysis by their sugar and glucosamine content. (with H. Fraenkel-Conrat, Miriam E. Simpson \& C. H. Li.) Science, N.Y. 89, 249.

Histological changes in skeletal musculature of paralyzed suckling young of E-low rats. (with I. R. Telford \& Gladys A. Emerson.) Proc. Soc. exp. Biol. Med. 41, 291.

Chemical fractionation of the gonadotropic factors present in sheep pituitary. (with $H$. Jensen, Miriam E. Simpson \& Sibylle Tolksdorf.) Endocrinology, 25, 57.

Degrees of sterility in female vitamin E-low rats. (with Gladys A. Emerson.) Am. F. Physiol. 126, 484.

Preservation of the seminiferous epithelium and of fertility in male rats by prophylactic administration of alpha tocopherol. (with Gladys A. Emerson \& O. H. Emerson.) Am. J. Physiol. 126, 487.

The preparation of pituitary growth hormone free from lactogenic and thyrotropic hormones. (with D. L. Meamber, H. L. Fraenkel-Conrat \& Miriam E. Simpson.) Science, N.Y. 90, 19.

Relation between the growth promoting effects of the pituitary and the thyroid hormone. (with Miriam E. Simpson \& R. I. Pencharz.) Endocrinology, 25, 175.

Biological studies of the gonadotropic principles in sheep pituitary substance. (with Miriam E. Simpson, Sibylle Tolksdorf \& H. Jensen.) Endrocrinology, 25, 529.

Restoration of fertility in successively older E-low female rats. (with Gladys A. Emerson.) F. Nutr. 18, 501.

Aspects of the function of vitamin $\mathrm{E}$ irrespective of its relation to the reproductive system. $\mathcal{F}$. Am. diet. Ass. 15, 869. 
Studies on pituitary lactogenic hormone. I. Electrophoretic behavior. (with C. H. Li \& W. R. Lyons.) 7. gen. Physiol. 23, 433.

Prevention of nutritional muscular dystrophy in suckling E-low rats with alpha-tocopherol and related substances. (with Gladys A. Emerson.) Proc. Soc. exp. Biol. Med. 44, 636.

Experimental superfecundity with pituitary gonadotropins. (with Miriam E. Simpson.) Endrocrinology, 27, 305.

Purification of thyrotropic hormone of the anterior pituitary. (with Jane Fraenkel-Conrat, H. FraenkelConrat \& Miriam E. Simpson.) 7. biol. Chem. 135, 199.

Further purification of the growth hormone of the anterior pituitary. (with H. L. Fraenkel-Conrat, D. L. Meamber \& Miriam E. Simpson.) Endrocrinology, 27, 605.

Successive generations of vitamin E-low rats. (with Gladys A. Emerson.) Proc. Soc. exp. Biol. Med. $45,159$.

Interstitial cell stimulating hormone. I. Biological properties. (with H. Fraenkel-Conrat, C. H. Li \& Miriam E. Simpson.) Endocrinology, 27, 793.

Interstitial cell stimulating hormone. II. Method of preparation and some physicochemical studies. (with C. H. Li \& Miriam E. Simpson.) Endocrinology, 27, 803.

Interstitial cell stimulating hormone. III. Methods of estimating the hormonal content of pituitaries. (with H. Fraenkel-Conrat \& Miriam E. Simpson.) Endocrinology, 27, 809.

Purification of follicle-stimulating hormone (FSH) of the anterior pituitary. (with H. L. FraenkelConrat \& Miriam E. Simpson.) Proc. Soc. exp. Biol. Med. 45, 627.

Studies on pituitary lactogenic hormone. II. A comparison of the electrophoretic behavior of the lactogenic hormone as prepared from beef and from sheep pituitaries. (with G. H. Li \& W. R. Lyons.) J. Am. chem. Soc. 62, 2925.

1941

Synergism of estrogens with pituitary gonadotropins in hypophysectomized rats. (with Miriam E. Simpson, H. L. Fraenkel-Conrat \& C. H. Li.) Endocrinology, 28, 37.

Studies on pituitary lactogenic hormone. III. Solubilities of sheep and beef hormones. (with C. H. Li \& W. R. Lyons.) F. gen. Physiol. 24, 303.

Effect of pituitary growth hormone on the thymectomized rat. (with W. O. Reinhardt \& W. Marx.) Proc. Soc. exp. Biol. Med. 46, 411.

Influence of lactogenic preparations on production of traumatic placentoma in the rat. (with Miriam E. Simpson \& W. R. Lyons.) Proc. Soc. exp. Biol. Med. 46, 586.

Anterior pituitary hormones which favor the production of traumatic uterine placentomata. (with Miriam E. Simpson, W. R. Lyons \& K. Turpeinen.) Endocrinology, 28, 933.

Effect of the pituitary growth hormone on the epiphyseal disk of the tibia of the rat. (with R. D. Ray \& H. Becks.) Am. F. Path. 17, 509.

Studies on pituitary lactogenic hormone. VI. Molecular weight of the pure hormone. (with C. H. Li \& W. R. Lyons.) F. biol. chem. 140, 45.

Growth hormone of the anterior lobe of the pituitary gland. F. Am. med. Ass. 117, 287.

Influence of lactogenic preparations on mammary glands and time of vaginal opening in young rats. (with W. R. Lyons \& Miriam E. Simpson.) Proc. Soc. $\exp$. Biol. Med. 48, 634.

Duality of pituitary gonadotrophins. Effects of FSH-ICSH mixture on hypophysectomized male and female rats. (with H. Fraenkel-Conrat, C. H. Li \& Miriam E. Simpson.) Proc. Soc. exp. Biol. Med. $48,723$.

The effect of different dose levels of growth hormone on the tibia of young hypophysectomized female rats. (with E. A. Kibrick, H. Becks \& W. Marx.) Growth, 5, 437.

The early effect of hypophysectomy and of immediate growth hormone therapy on endochondral bone formation. (with H. Becks, E. A. Kibrick \& W. Marx.) Growth, 5, 449.

\section{2}

Bioassay of the growth hormone of the anterior pituitary. (with W. Marx \& Miriam E. Simpson.) Endocrinology, 30, 1.

Effect of purified pituitary preparations on liver weights of hypophysectomized rats. (with $H$. L. Fraenkel-Conrat \& Miriam E. Simpson) Am. J. Physiol. 135, 398.

Effect of purified pituitary preparations on the insulin content of the rat's pancreas. (with H. L. Fraenkel-Conrat, V. V. Herring \& Miriam E. Simpson.) Am. 7. Physiol. 135, 404.

Effect of crystalline estrin implants on the proximal tibia and costochondral junction of young female rats. (with Miriam E. Simpson, E. A. Kibrick \& H. Becks.) Endocrinology, 30, 286.

Response to growth hormone of hypophysectomized rats when restricted to food intake of controls. (with W. Marx, Miriam E. Simpson \& W. O. Reinhardt.) Am. F. Physiol. 135, 614.

Physico-chemical characteristics of the interstitial cell stimulating hormone from sheep pituitary glands. (with C. H. Li \& Miriam E. Simpson.) 7. Am. chem. Soc. 64, 367. 
The bone histology of adult male rats thyroparathyroidectomized when one month of age. (with $\mathrm{H}$. Becks \& E. A. Kibrick.) 7. exp. Zool. 89, 297.

Synergism between thyrotropic and growth hormones of pituitary. Body weight increase in hypophysectomized rat. (with W. Marx \& Miriam E. Simpson.) Proc. Soc. exp. Biol. Med. 49, 594.

Urinary gonadotrophins in normal men. (with A. Gorbman.) Proc. Soc. exp. Biol. Med. 49, 674.

Biological properties of pituitary interstitial cell-stimulating hormone (ICSH). (with Miriam E. Simpson \& C. H. Li.) Endocrinology, 30, 969.

Comparison of methods for standardization of pituitary interstitial-cell-stimulating hormone (ICSH). (with Miriam E. Simpson \& C. H. Li.) Endocrinology, 30, 977.

Effects of crystalline estrin implants on the tibia of young hypophysectomized female rats. (with E. A. Kibrick, Miriam E. Simpson \& H. Becks.) Endocrinology, 31, 93.

Effect of thyroxin and the anterior pituitary growth hormone on endochondral ossification; species used: the rat. (with H. Becks, R. D. Ray \& Miriam E. Simpson.) Archs Path. 34, 334.

Effects of purified pituitary preparations on the nonprotein nitrogen constituents of blood. (with Jane Fraenkel-Conrat \& H. Fraenkel-Conrat.) Am. 7. Physiol. 137, 200.

Isolation of adrenocorticotropic hormone from sheep pituitaries. (with G. H. Li \& Miriam E. Simpson.) Science, $\mathcal{N} . Y .96,450$.

1943

Beginning of function in the thyroid of the fetal rat. (with A. Gorbman.) Endocrinology, 32, 113.

Bioassay of the pituitary growth hormone width of the proximal epiphyseal cartilage of the tibia in hypophysectomized rats. (with Miriam E. Simpson, W. Marx \& E. Kibrick.) Endocrinology, 32, 13.

Purification of the growth hormone of the anterior pituitary. (with W. Marx \& Miriam E. Simpson.) 7. biol. Chem. 147, 77.

Hormonal requirements for pregnancy and mammary development in hypophysectomized rats. (with W. R. Lyons \& Miriam E. Simpson.) Proc. Soc. exp. Biol. Med. 52, 134.

Effect of hypophysectomy and of purified pituitary hormones on the liver arginase activity of rats. (with H. Fraenkel-Conrat \& Miriam E. Simpson.) Am. F. Physiol. 138, 439.

Effect of growth hormone on glycosuria of fed partially depancreatized rats. (with W. Marx, Evelyn Anderson \& G. T. O. Fong.) Proc. Soc. exp. Biol. Med. 53, 38.

Antagonism of pituitary adrenocorticotropic hormone to growth hormone in hypophysectomized rats. (with W. Marx, Miriam E. Simpson \& C. H. Li.) Endocrinology, 33, 102.

Adrenocorticotropic hormone. (with C. H. Li \& Miriam E. Simpson.) F. biol. Chem. 149, 413.

Inhibiting effect of adrenocorticotropic hormone on the growth of male rats. (with Miriam E. Simpson \& C. H. Li.) Endocrinology, 33, 237.

Similarity of response of thymus and lymph nodes to administration of adrenocorticotropic hormone in the rat. (with Miriam E. Simpson, C. H. Li \& W. O. Reinhardt.) Proc. Soc. exp. Biol. Med. 54, 135.

Bioassay of adrenocorticotropic hormone. (with Miriam E. Simpson \& C. H. Li.) Endocrinology, 33, 261. The prophylactic requirement of the rat for alpha tocopherol. (with Gladys A. Emerson.) $\mathcal{F}$. Nutr. 26, 555.

Effects of purified antero-pituitary hormones on the carbohydrate stores of hypophysectomized rats. (with V. V. Herring.) Am. F. Physiol. 140, 452.

1944

Effect of adrenocorticotropic hormone on the insulin content of the rat's pancreas. (with $H$. FraenkelConrat, V. V. Herring \& Miriam E. Simpson.) Proc. Soc. exp. Biol. Med. 55, 52.

The isolation of pituitary growth hormone. (with C. H. Li.) Science, N.Y. 99, 183.

The bioassay of vitamin E. (with Gladys A. Emerson.) f. Nutr. 27, 469.

Effects of adrenocorticotropic hormone (ACTH) on the osseous system in normal rats. (with H. Becks, Miriam E. Simpson \& C. H. Li.) Endocrinology, 34, 305.

Antagonism of pituitary adrenocorticotropic hormone (ACTH) to the action of growth hormone on the osseous system of hypophysectomized rats. (with H. Becks, Miriam E. Simpson, W. Marx \& C. H. Li.) Endocrinology, 34, 311.

Sensitivity of the reproductive system of hypophysectomized 40 day male rats to gonadotropic substances (with Miriam E. Simpson \& G. H. Li.) Endocrinology, 35, 96.

The effect of pure adrenocorticotropic hormone on the work performance of hypophysectomized rats. (with D. J. Ingle \& C. H. Li.) Endocrinology, 35, 91.

Response of adrenalectomized-hypophysectomized rats to the pituitary growth hormone. (with Miriam E. Simpson, W. Marx \& H. Becks.) Endocrinology, 35, 234.

Effect of testosterone propionate on the body weight and skeletal system of hypophysectomized rats. Synergism with pituitary growth hormone. (with Miriam E. Simpson, W. Marx \& H. Becks.) Endocrinology, 35, 309. 
Isolation and properties of the anterior hypophyseal growth hormone. (with G. H. Li \& Miriam E. Simpson.) 7. biol. Chem. 159, 353.

Ossification at the proximal tibial epiphysis in the rat. I. Changes in females with increasing age. (with H. Becks \& Miriam E. Simpson.) Anat. Rec. 92, 109.

Production of glycosuria in normal rats by means of adrenocorticotropic hormone. (with D. J. Ingle, Helen A. Winter \& C. H. Li.) Science, N.Y. 101, 671.

Effect of adrenocorticotropic hormone (ACTH) on hypophysectomized adrenal-demedullated rats. (with Miriam E. Simpson \& C. H. Li.) Proc. Soc. exp. Biol. Med. 60, 329.

1946

Effects of chronic administration of diethylstilbestrol on the pituitary and other endocrine organs of hamsters. (with A. A. Koneff \& Miriam E. Simpson.) Anat. Rec. 94, 169.

Pantothenic acid deficiency and reproduction in the rat. (with Marjorie M. Nelson.) J. Nutr. $31,497$.

Response to pituitary growth hormone and thyroxin of the tibias of hypophysectomized rats after long postoperative intervals. (with H. Becks, Miriam E. Simpson, R. D. Ray, C. H. Li \& G. Willet Asling.) Anat. Rec. 94, 631.

Effect of adrenocorticotrophic hormone on urinary nitrogen excretion in the normal rat. (with G. S. Gordan, C. H. Li \& L. L. Bennett.) Proc. Soc. exp. Biol. Med. 62, 103.

The effect of adrenocorticotrophic hormone on the urinary excretion of sodium, chloride, potassium, nitrogen and glucose in normal rats. (with D. J. Ingle \& C. H. Li.) Endocrinology, 39, 32.

Continuous growth of normal rats receiving pure growth hormone. (with Miriam E. Simpson \& C. H. Li.) Endocrinology, 39, 71.

Sensitivity of the reproductive system of hypophysectomized forty-day-old male rats to testosterone propionate. (with Miriam E. Simpson.) Endocrinology, 39, 75.

Changes in the central incisors of hypophysectomized female rats after different postoperative periods. (with H. Becks, D. A. Collins \& Miriam E. Simpson.) Archs Path. 41, 457.

The hormones of the anterior pituitary. Am. J. Orthod. Oral Surg. 32, 472.

Comparison of the spermatogenic and androgenic properties of testosterone propionate with those of pituitary ICSH in hypophysectomized 40-day-old male rats. (with Miriarn E. Simpson.) Endocrinology, 39, 281.

\section{7}

Growth, reproduction and lactation in the rat maintained on purified diets. (with Marjorie M. Nelson.) Archs Biochem. 12, 213.

Effect of hypophyseal growth hormone upon rats fed low protein diets. (with G. S. Gordan, L. L. Bennett \& C. H. Li.) Proc. Soc. exp. Biol. Med. 65, 317.

Effects of testosterone propionate on body weight and urinary nitrogen excretion of normal and hypophysectomized rats. (with G. S. Gordan \& Miriam E. Simpson.) Endocrinology, 40, 375.

Récent progrès de nos connaissances sur les hormones du lobe antérieur de l'hypophyse. 7. Physiol., Paris, 39, 121.

The properties of the growth and adrenocorticotropic hormones. (with G. H. Li.) Vitams Horm. 5, 197.

1948

Ossification at the distal end of the humerus in the female rat. (with H. Becks, C. Willet Asling, Miriam E. Simpson \& C. H. Li.) Am. F. Anat. 82, 203.

Results of administration of anterior pituitary adrenocorticotropic hormone to a normal human subject. (with H. L. Mason, M. H. Power, E. H. Rynearson, Letizia G. Giaramelli \& G. H. Li.) J. clin. Endocr. 8, 1.

Production of ketosis by the growth and adrenocorticotropic hormones. (with L. L. Bennett, Ruth E. Kreiss \& C. H. Li.) Am. F. Physiol. 152, 210.

Skeletal changes in rats thyroidectomized on the day of birth and the effects of growth hormone in such animals. Tibia, metacarpal and caudal vertebrae. (with $\mathrm{H}$. Becks, Miriam E. Simpson. R. O. Scow \& C. Willet Asling.) Anat. Rec. 100, 561.

The effect of dietary protein content upon the nitrogen retention and weight gain produced by the hypophyseal growth hormone. (with G. S. Gordan, L. L. Bennett \& C. H. Li.) Endocrinology, 42, 153.

The gigantism produced in normal rats by injection of the pituitary growth hormone. I. Body growth and organ changes. (with Miriam E. Simpson \& C. H. Li.) Growth, 12, 15.

The gigantism produced in normal rats by injection of the pituitary growth hormone. II. Histological changes in the pituitary. (with A. A. Koneff, Miriam E. Simpson \& C. H. Li) Growth, 12, 33.

The gigantism produced in normal rats by injection of the pituitary growth hormone. III. Main chemical components of the body. (with C. H. Li \& Miriam E. Simpson.) Growth, 12, 39. 
The gigantism produced in normal rats by injection of the pituitary growth hormone. IV. Skeletal changes: Tibia, costochondral junction, and caudal vertebrae. (with H. Becks, C. Willet Asling, Miriam E. Simpson \& C. H. Li.) Growth, 12, 43.

The gigantism produced in normal rats by injection of the pituitary growth hormone. V. Skeletal changes: Skull and dentition. (with H. Becks, D. A. Collins, C. Willet Asling, Miriam E. Simpson \& C. H. Li.) Growth, 12, 55.

The beneficial effects of biotin on lactation in the rat. (with Marjorie M. Nelson.) Archs Biochem. 18, 477.

Crystallization of hypophyseal growth hormone. (with G. H. Li \& Miriam E. Simpson.) Science, N.Y. $108,624$.

Chemistry of anterior pituitary hormones. (with G. H. Li.) In: The Hormones, I, 631. Eds. G. Pincus and K. V. Thimann. Academic Press, N.Y.

1949

Influence of growth and adrenocorticotropic hormones on the body composition of hypophysectomized rats. (with C. H. Li \& Miriam E. Simpson.) Endocrinology, 44, 71.

The influence of growth and adrenocorticotropic hormones on the fat content of the liver. (with C. H. Li \& Miriam E. Simpson.) Archs Biochem. 23, 51.

The effect of adrenocorticotropic and growth hormones on the glucose uptake and glycogen synthesis by the isolated diaphragm with and without insulin. (with C. H. Li \& C. Kalman.) Archs Biochem. 23, 512 .

Bioassay of hypophyseal growth hormone: The tibia test. (with F. S. Greenspan, C. H. Li \& Miriam E. Simpson.) Endocrinology, 45, 455.

The search for the diabetogenic principle of the anterior hypophysis. (The Banting Memorial Address.) Proc. Am. Diabetes Ass. 9, 49.

\section{0}

Neoplasm in rats treated with pituitary growth hormone. II. Adrenal glands. (with H. D. Moon, Miriam E. Simpson \& C. H. Li.) Cancer Res. 10, 364.

Effects of the pituitary growth hormone and of thyroxin on growth and differentiation of the skeleton of the rat thyroidectomized at birth. (with R. D. Ray, Miriam E. Simpson, C. H. Li \& C. Willet Asling.) Am. F. Anat. 86, 479.

Failure of hypophyseal growth hormone to produce nitrogen storage in a girl with hypophyseal dwarfism. (with L. L. Bennett, H. Weinberger, R. Escamilla, S. Margen \& C. H. Li.) J. clin. Endocr. Metab. 10, 492.

Neoplasms in rats treated with pituitary growth hormone. III. Reproductive organs. (with H. D. Moon, Miriam E. Simpson \& G. H. Li.) Cancer Res. 10, 549.

The partition of liver nucleic acids after hypophysectomy and growth hormone treatment. (with I. Geschwind \& C. H. Li.) Archs Biochem. 28, 73.

Physiology of the gonadotrophins. (with M. E. Simpson) In: The Hormones, II. Chap. VI, 351. Eds. G. Pincus and K. V. Thimann. Academic Press, N.Y.

The hypophysis and diabetes mellitus. In: The Hormones, II. Chap. VIII, 405. Eds. G. Pincus and K. V. Thimann. Academic Press, N.Y.

Direct action of the male sex hormone on the adrenal cortex. (with L. A. Zizine \& Miriam E. Simpson.) Endocrinology, 47, 97.

Some endocrine influences on skeletal growth and differentiation. (with Miriam E. Simpson \& C. Willet Asling.) Tale 7. Biol. Med. 23, 1.

The effects of hypophysectomy, growth and adrenocorticotropic hormones on the incorporation of $P^{32}$ into liver phospholipids. (with I. I. Geschwind \& G. H. Li.) Endocrinology, 47, 162.

Preparation of nonprotein fractions possessing adrenocorticotropic activity from fresh sheep pituitary glands. (with I. I. Geschwind, G. P. Hess, P. G. Condliffe \& Miriam E. Simpson.) Science, N.Y. $112,436$.

Survival in the circulation of the growth and adrenocorticotrophic hormones as evidenced by parabiosis. (with D. C. Van Dyke, Miriam E. Simpson \& C. H. Li.) Am. J. Physiol. 163, 297.

1951

Neoplasms in rats treated with pituitary growth hormone. IV. Pituitary gland. (with A. A. Koneff, H. D. Moon, Miriam E. Simpson \& C. H. Li.) Cancer Res. 11, 113.

Effect of pyridoxine on reproduction of the rat. (with Marjorie M. Nelson.) J. Nutr. 43, 281.

The effects of hypophysectomy and of growth hormone on the uptake of radioactive phosphorus by tissues. (with I. I. Geschwind \& C. H. Li.) Archs Biochem. Biophys. 31, 168.

Neoplasms in rats treated with pituitary growth hormone. V. Absence of neoplasms in hypophysectomized rats. (with H. D. Moon, Miriam E. Simpson \& G. H. Li.) Cancer Res, 11, 535. 
Synergism between pituitary follicle stimulating hormone (FSH) and human chorionic gonadotropin (HCG). (with Miriam E. Simpson \& C. H. Li.) Endocrinology, 48, 370.

Maintenance of pregnancy in pyridoxine-deficient rats when injected with estrone and progesterone. (with Marjorie M. Nelson \& W. R. Lyons.) Endocrinology, 48, 726.

Increase in the formation and secretion of ACTH following adrenalectomy. (with C. A. Gemzell, D. C. Van Dyke \& C. A. Tobias.) Endocrinology, 49, 325.

1952

Effect of pituitary growth hormone in mice. (with H. D. Moon, Miriam E. Simpson, \& C. H. Li.) Cancer Res. 12, 448.

Inhibition of methylcholanthrene carcinogenesis by hypophysectomy. (with H. G. Moon \& Miriam E. Simpson.) Science, N.Y. 116, 331.

Production of multiple congenital abnormalities in young by maternal pteroylglutamic acid deficiency during gestation. (with Marjorie M. Nelson \& G. Willet Asling.) J. Nutr. 48, 61 .

Deaths in rats submitted to hypophysectomy at an extremely early age and the survival effected by growth hormone. (with C. W. Asling, D. G. Walker, M. E. Simpson \& C. H. Li.) Anat. Rec. 114, 49.

Structural alterations in rats hypophysectomized at six days of age and their correction with growth hormone. (with D. C. Walker, C. W. Asling, Miriam E. Simpson \& C. H. Li.) Anat. Rec. 114, 19.

Increase in the thyrotropic hormone content of blood after thyroidectomy as shown by parabiosis. (with A. A. Koneff \& D. G. Van Dyke.) Endocrinology, 51, 249.

1953

Regeneration of the calvarium in young normal and growth hormone-treated hypophysectomized rats. (with Miriam E. Simpson, D. C. Van Dyke and C. W. Asling.) Anat. Rec. 115, 615.

Comparison of ovarian and pituitary hormones for maintenance of pregnancy in pyridoxine-deficient rats. (with M. M. Nelson \& W. R. Lyons.) Endocrinology, 52, 585.

The effect of growth hormone on tibia-glycogen content of the hypophysectomized rat. (with S. Ellis \& Miriam E. Simpson.) Endocrinology, 52, 554.

Relation of dietary protein levels to reproduction in the rat. (with M. M. Nelson.) 7. Nutr. 51, 71.

Qualitative changes in urinary gonadotrophins in human pregnancy during the period of rapid increase in hormone titer. (with R. A. Lyon \& Miriam E. Simpson.) Endocrinology, 53, 674.

1954

Growth and differentiation of the skeleton in thyroidectomized-hypophysectomized rats treated with thyroxin, growth hormone, and the combination. (with R. D. Ray, G. W. Asling, D. G. Walker, Miriam E. Simpson \& C. H. Li.) 7. Bone ft Surg. 36-A, 94.

The effects of chronic administration of thyroxin to hypophysectomized rats on their skeletal growth, maturation and response to growth hormone. (with C. Willet Asling, Miriam E. Simpson \& C. H. Li.) Anat. Rec. 119, 101 .

Purity of growth hormone prepared by different methods. (with S. Ellis, G. Noda \& Miriam E. Simpson.) 7. biol. Chem. $209,779$.

Maintenance of pregnancy in the absence of dietary protein with estrone and progesterone. (with Marjorie M. Nelson.) Endocrinology, 55, 543.

Congenital cardiovascular anomalies induced by pteroylglutamic acid deficiency during gestation in the rat. (with Catherine D. C. Baird, Marjorie M. Nelson \& I. W. Monie.) Circulation Res. 2, 544.

Growth hormone-induced osteoarthropathy. (with Miriam E. Simpson, H. D. Moon \& G. H. Li.) Proc. Am. Rheum. Ass.

1955

Effect of pyridoxine deficiency on the gonadotrophic content of the anterior pituitary in the rat. (with Eloise Wooten, Marjorie M. Nelson \& Miriam E. Simpson.) Endocrinology, 56, 59.

Purification of the anterior hypophyseal thyrotrophic hormone. (with I. Gorden Fels \& Miriam E. Simpson.) 7. biol. Chem. 123, 311.

Relation of thiamine to reproduction in the rat. (with Marjorie M. Nelson.) 7. Nutr. 55, 151.

Maintenance of pregnancy in absence of dietary protein with progesterone. (with Marjorie M. Nelson.) Proc. Soc. exp. Biol. Med. 88, 444.

Growth hormone induced bone and joint changes in the adult rat. (with C. W. Asling, Miriam E. Simpson, H. D. Moon \& C. H. Li.) In: The Hypophyseal Growth Hormone, Nature and Action, Ghap. 9, 154. Eds. R. W. Smith, Jr, O. H. Gaebler and C. N. H. Long. McGraw-Hill, New York.

Multiple congenital abnormalities resulting from transitory deficiency of pteroylglutamic acid during gestation in the rat. (with Marjorie M. Nelson, H. V. Wright \& C. Willet Asling.) 7. Nutr. 56, 349. 
1956

Anterior pituitary regulation of skeletal development. (with G. W. Asling) In: The Biochemistry and Physiology of the Bone, Chap. 21,671. Ed. G. H. Bourne, Academic Press, New York.

1957

Ossification at the proximal end of the femur in female rats (Long-Evans strain.) I. Changes with increasing age. II. Changes following hypophysectomy. III. Changes following injections of growth hormone, thyroxin, and their combinations. (with J. J. Pindborg \& H. Becks.) Acta endocr., Copenh. 26, 142.

Hormonal control of ossification of the caudal vertebrae in the rat. I. Physiological changes in females with increasing age. A. Metric and roentgenographic study. (with L. J. Baume \& H. Becks.) Helv. odont. Acta 1, 9.

Hormonal control of ossification of the caudal vertebrae in the rat. I. Physiological changes in females with increasing age. B. Histological study. (with L. J. Baume \& H. Becks.) Helv. odont. Acta 1, 38.

1958

Prenatal development of the skeleton in Long-Evans rats. (with Howard V. Wright, C. Willet Asling, H. L. Dougherty \& Marjorie M. Nelson.) Anat. Rec. 130, 659.

The role of growth hormone in calorigenesis and thyroid function. (with E. S. Evans \& Miriam E. Simpson.) Endocrinology, 63, 836.

Response of vitamin $B_{6}$-deficient rats to hypophyseal follicle-stimulating and interstitial-cell-stimulating hormones. (with Eloise Wooten, Marjorie Nelson \& Miriam E. Simpson.) Endocrinology, 63, 860.

1959

Dietary requirement for lactation in the rat and other laboratory animals. (with Marjorie $M$. Nelson.) In: Milk: Its Physiology and Biochemistry, Eds. A. T. Cowie and S. K. Kon. Academic Press, New York.

Men and moments in the history of science, Ed. H. M. Evans. Anniversary volume commemorating the founding of the History of Science Dinner Club on the University of California campus Sept. 12, 1933. University of Washington Press, Seattle. 


\title{
THE OESTROUंS CYCLE IN THE RAT AND OTHER STUDIES IN THE PHYSIOLOGY OF REPRODUCTION
}

\author{
BY \\ JOSEPH A. LONG AND HERBERT M. EVANS
}

MARCH, 1920 
Reprinted from The Asstourcat Recond, Volume 18, Number 3, April, 1920 .

1. The oestrus cycle in the rat. Joseph A. Long and Herbert M. Evans, University of California.

(Abstracts of a monographic account of the physiology of reproduction in the rat to be published at an early date.)

Observations on the living animal. During the last three years a great many observations on several hundred healthy young adult rats have established the-existence of a typical oestrous cycle for this animal. Five stages may be distinguished in this cycle by means of characteristic changes in the cellular- and fluid-content of the vagina, changes which stand in a definite relation with alterations in the external appearance of the genitals and with equally definite changes in the uterus and ovary.

The normal length of this cycle lies between four and five days. About one-half of the time occupied by the cycle is represented by the so-called quiescent stage or pause (the dioestrous interval of Heape) or stage 4 of our notation, and the remaining half of the cycle is involved in the more active changes associated with the phenomena of oestrus and ovulation, which have been designated as stages $0,1,2$, and 3 , respectively. These four stages might appropriately be designated as the preparation for oestrus, the period of oestrus proper, the period of ovulation, and the period of epithelial tissue destruction accompanied by leucocytic infiltration.

From the statement above concerning the time occupied by the dioestrous interval it is evident that about half of all animals examined at any one time will be found in this quiescent stage. At any time during this phase of the cycle the vaginal mucosa as examined with the speculum is pinkish, moist, and glistening, and the vaginal content, removed by spatula or other appropriate instrument, consists of a variable quantity of thin, somewhat stringy mucus with which are entangled variable numbers of leucocytes and epithelial cells.

Stage 0 , which we have termed the preparation for oestrus (Heape's pro-oestrum), is characterized by a sudden change in the vaginal smear, from which almost all of the fluid and all of the leucocytes have now disappeared, the smear consisting exclusively of great numbers of epithelial cells of strikingly uniform size occurring singly or in sheets. Associated with this change in the smear, which we have adopted as a criterion of stage 0 , are equally marked changes in the gross appearance of the vaginal mucosa, for the latter has become somewhat drier and less glistening. In some animals a further external characteristic of the stage may be found in an increasing turgescence of the radiating folds about the vaginal aperture. The average duration of the stage 
is twelve hours. Toward the end of it a certain portion of females will copulate.

Stage 1 is characterized by an equally definite change in the vaginal smear for the nucleated epithelial cells characteristic of stage 0 are rather suddenly replaced by cornified cells, large, transparent, nonnucleated, scale-like elements which during this stage do not accumulate in macroscopic amounts. The smear still remains free from leucocytes, which had been present during the dioestrous interval and whose sudden disappearance was so marked a characteristic of the preceding stage. The speculum discloses a vaginal mucosa at this stage much less translucent than usual, whitish in color, lusterless, and dry. The turgescence of the vaginal opening which has been noted in the preceding stage may continue or be evident for the first time. All of the normal animals tested by us at this stage manifest oestrous excitement and will copulate.

Stage 2, which cannot be separated abruptly from stage 1 , nevertheless differs from it in two marked particulars, first, in the accumulation of such considerable quantities of cornified cells as to form easily visible masses of whitish, granular substance within the cavity of the vagina and, secondly, in the fact that animals in this stage will no longer accept coitus. The vaginal smear shows that the white, granular masses consist exclusively of enormous numbers of cornified cells without the addition of leucocytes or other elements. The average length of stages 1 and 2 is twenty-seven hours.

Stage 3 is inaugurated by the appearance in the vaginal smear of leucocytes among the cornified cells and ends with the disappearance of the latter. The leucocytes cause a softening of the granular masses of the latter to a cheesy, creamy, and increasingly fluid consistency. Before the cornified cells have completely vanished epithelial cells reappear, so that during a short interval all three cellular types are present (cornified, non-cornified, and leucocytes). This ushers in the beginning of the dioestrous pause, which may be recognized by the disappearance of cornified elements and the domination of the smear by leucocytes and epithelial cells. Stage 3 is normally of about six hours' duration.

Correlated conditions found in sections of vagina, uterus, oviduct, and ovary. Histological changes in every portion of the reproductive tract are correlated with the above stages which we have characterized by means of the vaginal smear.

During the dioestrous interval the vaginal mucosa is thin (four to seven cell layers) and the squamous transformation of its upper cells only slight. It remains infiltrated. by leucocytes and constantly decreases in thickness through dehiscence of its superficial cells, a process evidently not completely compensated for by mitosis in the basal layer. Near the end of the 'interval' the epithelium becomes somewhat thicker (eight to nine cells), the squamous transformation more marked, and the surface cells swollen in a characteristic way to become a well-defined layer (the layer of ' 0 cells'). The uterus during the 
dioestrous interval is always slender and with a slit-like lumen; eggs from the preceding ovulation may be recognized in the proximal portion of the oviduct, even in the middle of the interval. The ovary contains moderately large follicles and well-developed corpora.

The stage preparatory to oestrus, which we have designated as stage 0 , shows the vaginal epithelium now having attained its greatest height (nine to twelve cells) and the development of a cornified layer and stratum granulosum under the superficial layer of swollen epithelial cells which, when detached, constitutes the cells of the vaginal smear typical of this stage. ${ }^{1}$ Leucocytic migration into the epithelial has ceased. The uterus, which is hyperaemic toward the end of stage 0 , becomes distended with fluid, its epithelium changing thereby from columnar to cuboidal. The fluid probably serves as a medium through -which spermatozoa may swim rapidly toward the oviduct since spermatozoa from the vasa deferentia when added to such fluid become very active. The ovary shows a continued growth of follicles.

Stage 1, characterized by a vaginal smear in which cornified cells have replaced the epithelial elements of stage 0 , shows a vaginal mucosa in which the stratum cornium is now superficial. The latter aided by the general height of the epithelium doubtless causes the dry and lusterless appearance of the mucosa in the gross, and by gradual dehiscence furnishes the cells of the smear. The epithelium is still free from leucocytes. The uterus exhibits its most marked vascular congestion and reaches its greatest distention in the early part of this stage. The distention disappears about the end of the stage, . when a columnar epithelium succeeds the cuboidal type found at the time of maximum diameter. The phenomena of hyperaemia and the distention of the uterus beginning in the latter part of stage 0 and reaching their culmination in the first part of. stage 1 correspond accurately with the period of maximum exhibition of oestrus. During stage 1 the ovarian follicles reach their maximum size, and toward the end of it the first maturation division may be detected.

Stage 2 is characterized by a continued reduction of the vaginal epithelium (five to nine cells), by the complete detachment of the stratum cornium, and the disappearance of the usual, thin, subjacent stratum granulosum. It will be remembered that this is the stage of accumulation of considerable granular masses in the vaginal lumen. Leucocytes have not yet entered the epithelium in any numbers. The epithelium of the uterus at stage 2 begins to undergo a degeneration char-

I The appearance of the cornified layer actually beneath the surface of the epithelium is a remarkable histogenetic process noted long ago, but not accurately described, by Retterer and apparently lost sight of entirely by subsequent investigators. The French observer recognized the process in several forms. Subsequently to the above observations, we have been able to satisfy ourselves of its occurrence in the guinea-pig, and Corner and Pelkan in the rabbit. It constitutes one of the few omissions in the model papers on oestrus. in the guinea-pig by Stockard and Papanicolaou whose work marks so significant a step.in our knowledge of this subject. 
acterized by the enlargement of 'vacuolar' cavities. Stage 2 is further typified by the occurrence of ovulation.

In stage 3 , the smear of which is characterized by cornified cells admixed with leucocytes, the vaginal epithelium becomes progressively lower (four to eight cells), and through complete dehiscence no vestige of the stratum cornium or granulosum can be found, unless it be in isolated patches in the vagina. . An extensive leucocytic infiltration of the vaginal epithelium is now manifested. The uterine epithelium is still undergoing its 'vacuolar' degeneration and leucocytic infiltration may also be detected there. Eggs are normally encountered traversing the oviduct, while the ovary is characterized by the vigorous growth of the newly formed corpora lutea.

Length of the cycle. About two thousand cycles have been observed in some three hundred animals, many of which were observed for as many as twenty consecutive cycles. As may be seen by the accompanying table, by far the most of the cases ( 82 per cent) are of oestrus cycles four, five, and six days in length. Records of the succession of cycles in individual rats show such considerable variations that it may be said that only about 50 per cent of all animals have cycles which may be depended upon to vary by less than two days in length. Even in the latter group, some individuals exhibit curious instances of a longer cycle interpolated in a long series of regular cycles of normal duration. One may also point out that a small proportion of all perfectly normal individuals exhibit such irregularity in their cycles as to be unavailable for experimental work.

Table of observed instances of oestrus cycles of various lengths

\begin{tabular}{|c|c|c|c|}
\hline LENGTH OF CYCLE IN DAYS & \multicolumn{3}{|c|}{ NUMBER OF INSTANCES } \\
\hline $\begin{array}{r}3 \\
4 \\
5 \\
6 \\
7 \\
8 \\
9 \\
10 \\
11 \\
12 \\
13 \text { and over }\end{array}$ & $\left.\begin{array}{r}65 \\
789 \\
634 \\
233 \\
69 \\
60 \\
30 \\
24 \\
\mathbf{1 6} \\
22 \\
57\end{array}\right\}$ & $\left\{\begin{array}{l}\ldots 82 \% \\
\ldots 92 \%\end{array}\right.$ & $\begin{array}{l}\text { Average } 4.6 \text { days } \\
\text { Average } 4.8 \text { days }\end{array}$ \\
\hline & 1999 & General & average 5.4 days \\
\hline
\end{tabular}

2. On the attainment of sexual maturity and the character of the first oestrus cycle in the rat. Josepr A. Long and Herbert M.. Evans, University of California.

Careful observations have been carried out on considerably more than two hundred animals from the time of weaning until the attainment of sexual maturity. While these data are insufficient for statis- 
tical purposes, they nevertheless demonstrate clearly the great variation in the time of onset of puberty which may be attained as early as the forty-fifth or delayed until the one hundred and twentieth day. Similarly, sisters of the same litter show a great variation, though seldom of this maximum extent. These facts would appear of much importance in the light of reputed influence on sexual maturity of various experimental procedures, especially endocrine therapy (vida Goetsch, '16). The data, which will be greatly enlarged, indicate that about 16 per cent of all individuals are mature by the sixtieth day of age, 30 per cent about the seventieth, somewhat over 60 per cent by the eightieth, somewhat over 80 per cent by the ninetieth, and fully 95 per cent by the one hundredth day. They indicate further that in spite of the existence of this variation more than half of all cases would appear to mature in the interval between the seventieth and ninetieth days. We have defined maturity as the opening of the vaginal orifice. The thin epithelial membrane which forms at the site of the future introitus and which is not without -resemblance to a cicatrix ruptures spontaneously The first ovulation is coincident with this event, as sections of the ovaries and oviduct demonstrate. In many cases the vaginal smear shows at the time of opening stages 0 to 2 , so that a typical oestrus is present. The rupture of the vaginal membrane may take place in two areas, leaving a vertical median cord which may persist throughout the first gestation.

Many observations show that the first two or three oestrus cycles which succeed the initial one are usually longer than those which occur later.

3. Effect on the oestrus cycle of the removal of various portions of the reproductive system. Joseph A. Long and Herbert M. Evans, University of California.

Removal of the entire uterus including the cervix does not influence the regular recurrence of oestrus other than through an initial delay which occurs in some cases, doubtless as a result of the shock of the operation. Double ovariotomy causes a complete cessation of oestrus, although the excision of the ovaries just preceding an expected oestrus may not influence the occurrence of that particular oestrus.

4. Rhythmical recurrence of the typical oestrus cycle after ovarian transplantation. Joseph A. LoNG and Herbert M. Evans, University of California.

Fourteen instances of successful transplantation of the ovaries into the spleen, mesometrium, and rectus muscle have been secured and the oestrus cycles of these followed for somewhat over four months after the operation. Recognition of the vaginal changes associated with oestrus furnishes a positive method for the detection of the surgical success of the transplant and proof of the continued physiological function of the same. In most successful cases, the first interval after the operation was only slightly longer than the dioestrous interval of normal cycles. Sections show that such transplanted ovaries are essen- 
tially normal in containing healthy and atretic follicles, corpora lutea of several ages, and interstitial tissue. They demonstrate that in the absence of any true ovulation there is nevertheless an apparent rhythmic production of corpora lutea from unburst follicles as is known to occur rarely in normal animals.

5. The effect of copulation in delaying the occurrence of the next oestrus cycle and the production of a similar effect by mechanical stimulation of the cervix. Joseph A. Long and Herbert M. Evans, University of California.

When normal females of the rat are permitted to copulate with vasectomized males some of the effects of coitus other than conception may be secured. The 'plug' (which, as Walker has shown, is the result of the secretion of the prostate and a special gland, the coagulating gland), although free from sperm, is nevertheless ejaculated by such males and fills the vaginal lumen. Females which have been mated in this way, although not becoming pregnant, usually show a delay of from four to ten days in the appearance of the next oestrus. A similar effect may be secured when normal males are mated with females suffering from complete stricture of the oviducts. It was thought possible that this delay in the oestrus might be due to some portion of the prostatic secretion, and this substance was consequently injected into the uterus through the cervical canal. The injection of Ringer's solution in the same way was, however, found to give the same effect. Finally, the correct explanation was discovered in the irritation of the cervix itself which the glass canulae had caused, for the simple introduction of a small glass rod gives an identical response. Not more than $1 \mathrm{~mm}$. of the cervical canal need be traversed in order to secure the effect.. It is hence altogether likely that the simulation of the effect of copulation by mechanical stimulation is due to the fact that the hard vaginal plug impinges upon and protrudes slightly into the cervical canal. The effect may be produced with equal ease after hysterectomy and in animals in which the mammary glands have been completely excised shortly after birth. The effect may similarly be produced after. double ovariotomy, providing normal oestrus cycles have secondarily been secured by successful transplantation of the ovaries. It would appear unlikely that this may be explained on the basis of any reflex nervous effect on the ovary itself. Stimulation of the uterine mucosa by an aperture in its peritoneal surface rather than through the cervix, has not shown such an effect. The effect is consequently peculiar to the cervical mucosa; most of which is lined by a typical stratified, squamous epithelium. It is produced with greatest reliability during stages 0,1 , and 2 of the oestrus cycle. The delay in the appearance of oestrus is correlated with a similar delay in ovulation, as has been established by the administration of vital dye to mark all corpora lutea present at the time of cervical stimulation: It would not appear improbable that this delay is a contrivance to ensure implantation. The time relations involved are significant. In the rat four days occur between copulation and the 
arrival of segmenting ova in the uterus. According to our work, a new cycle would be under way at that time if oestrus had not been delayed in this way by the effect of copulation. Furthermore, experimental deciduomata undergo complete regression with the onset of the next oestrus, and it is consequently possible that could oestrus occur it would prevent implantation.

6. The inhibition of oestrus and ovulation by lactation. JosepH A. LONG and Herbert M. Evans, University of California.

Young rats may usually be weaned after twenty-one days of suckling, but if left with the mother the duration of lactation may be almost double this time. Daily microscopic examinations of the vaginal smear from suckling mothers show the persistence of the condition characterizing the dioestrous interval. Typical oestrous changes recur in from three to twelve days after the removal of the young and will occur spontaneously before the end of greatly prolonged periods of nursing.

Proof that ovulation does not occur during this period is furnished by use of vital dye administered during pregnancy in order to mark the corpora of gestation. If animals are now killed during lactation, only a single unstained set of corpora are found, the corpora of lactation. On the incidence of an oestrus cycle after the removal of the young, the first other corpora to be found now add themselves to those already present. Instances of pregnancy occurring early in lactation are due to fruitful copulation on the day of littering, and in such instances the same corpora function simultaneously as those of lactation and of the second pregnancy.

7. Corpora lutea of lactation in the rat as distinguished from the corpora of pregnancy and those of ovulation. JOSEPH A. LONG and HerberT M. Evans, University of California.

Certain vital dyes administered during the last week of pregnancy are deposited in the cells of the only corpora lutea then present (corpora lutea gravidatis). We have experimented with somewhat over seventy substances of known chemical constitution and found but two suited for such a purpose, the benzidine dye formed by the combination of dichlorbenzidine with two molecules of 1.8 aminonaphthol 3.6 disulphonic acid, and that formed by combining orthotolidine with a molecule each of the Neville-Winther acid and of chromatropic acid. Toxicity of the first dyestuff renders it unreliable for work in which we must be certain to preserve normal physiological conditions, but the second vital color is not open to this objection. The dye persists in the corpora up to the time of their disappearance and consequently serves as a means of identification of them, for corpora arising subsequently to dye treatment are not stained.

In the ovaries of rats treated in this manner and killed, for example, at the end of the first week of lactation two kinds of corpora lutea may be recognized, those possessing dye deposits and those which are uncolored. The latter are consequently recent structures and must all result from the ovulation well known to occur within twenty-four hours 
after littering. They may appropriately be termed corpora lutea of lactation and differ in size and structure from both of the other types of corpora. These corpora are intermediate in size between the corpora of pregnancy and those of ovulation. It is interesting that even in cases of prolonged lactation, where they may be considered as functioning longer than do the corpora of gestation, they do not attain the greatest size reached by the latter. Structurally, a pronounced difference from other corpora is found in the characteristic picture of uniformly distributed, very small lipoid granules possessed by the lactation lutein cells. Although the process of suckling thus produces characteristic changes in corpora lutea, the latter structures and; indeed, the ovary itself are unnecessary for the further performance of lactation.

8. The survival and time of disappearance of the corpora lutea of pregnancy in the rat under various conditions. JOSEPH A. LONG and HeRBERT M. EVANS, University of California.

If the corpora lutea of pregnancy are dyed vitally during the last week of gestation, they may be recognized subsequently as long as they persist in the ovary. With advancing age the lutein cells lose their deposits of vital dye and become fewer in number until their disappearance. The vital dye, however, remains, within the confines of the corpus, having been taken up by macrophages which assemble at the beginning of degeneration and become gorged with color.

Under the simplest conditions, i.e., when the animal neither suckles nor becomes pregnant again, vestiges of these corpora of gestation may be detected with the naked eye as small blue spots as late as more than one hundred days postpartum. Under these conditions the ovary comes to contain a large number of small corpora lutea of ovulation formed, as we now know, at intervals of from four to five days. The first set of these corpora is formed from the ovulation which invariably occurs within twenty-four hours after littering. If the animal is allowed to suckle her young or to become pregnant again, the corpora of this ovulation become transformed into corpora of lactation or pregnancy. In the presence of the latter structures which grow rapidly the corpora of the preceding pregnancy degenerate much earlier.

9. The experimental production of deciduomata in the rat, with special reference to the phases of the oestrus cycle. JosepH A. Long and HerBERT M. Evans, University of California.

The possibility of the experimental production of deciduomata discovered by Leo Loeb working with the guinea-pig and confirmed by Frank and by Corner and Warren in the rat can now be studied in its relation to phases of the oestrus cycle. Such a correlation is necessary in order to inquire into the validity of the theory of the participation of young corpora lutea in the phenomenon of implantation by their supposed secretion of a hormone which sensitizes the uterine mucosa.

Deciduomata of appreciable size are difficult to produce during the normal short oestrus cycle which characterizes the rat, but may reach 
a larger size if the uterine operation is carried out from four to six days after a mechanical stimulation of the cervix.. As has been shown separately; such a stimulation produces the same effect in delaying the appearance of the next oestrus cycle as does copulation. The fact that the uterine growths are most pronounced when the operation is carried out within this time interval (the cervical stimulation always being performed at stages 0 or 1 of the normal oestrus cycle) would appear significant in the light of our knowledge that normal implantation occurs at this time. Such large deciduomata undergo complete regression and absorption on the incidence of the next oestrus, a sufficient explanation of the difficulty of producing deciduomata unless the cycle is artificially prolonged. However, the inhibition of oestrus by lactation is not favorable for deciduomata formation, and it would appear from this that the uterine mucosa during nursing is not in the same condition as it is succeeding coitus. The deciduomata reaction cannot be induced in the presence of a pregnancy. The retention of the foreign body (silk thread, etc.) in the uterus does not produce a second deciduomatous response after the resorption of the first.

10. A characteristic sign of pregnancy in the rat detectable from the thirteenth to the sixteenth day. Josepr A. Long and Herbert M. Evans, University of California.

Although inspection of the uterus by means of laparotomy will disclose enlargement at the implantation sites as early as the seventh day of gestation, external signs of conception are not evident until considerably later. An increase in size is apparent about the eighteenth day and a presumptive diagnosis may be made somewhat earlier by successive increases in weight. Daily vaginal examinations with the speculum make it possible to detect pregnancy as early as the thirteenth day by the presence of a bright red coloration on the ventral wall of the vagina and near the cervix. The sign appears abruptly and persists until the sixteenth day, the reddish color changing to brown. The vaginal smear displays considerable numbers of free red corpuscles which are never present here during any phases of the normal oestrous cycle or at any other time in the rat. 


\title{
FURTHER STUDIES IN THE PHYSIOLOGY OF REPRODUCTION
}

\author{
BY \\ JOSEPH A. LONG AND HERBERT M. EVANS
}

MARCH, 1921 
Reprinted from The Anstomical Recond, Volume 21, Numbex 1, April, 1921

(Further studies on the physiology of reproduction include abstracts 26 to 34. )

26. Proportion of ova producing full-term young in the rat. Joseph A. LoNg and Herbert M. Evans, University of California.

We are beginning to appreciate the widespread and customary occurrence of departures from perfect functioning of the mammalian reproductive apparatusdepartures which reduce fertility. These may be due to fault with ovary, tube, or uterus. They are occurring continually. During the last three years we have recorded the number of young in 625 litters of the rat. The average lies between six and seven. During this period of time fifty animals were sacrificed within one day after ovulation and at least one oviduct and ovary cut serially. In all instances the eggs from this ovulation were encountered in the tube and were enumerated. An average was found of 4.8 eggs in each oviduct or $9.6 \mathrm{eggs}$ per ovulation. Other material in which the eggs could not be enumerated with reliability, but in which the corpora lutea of a single ovulation could be counted, was studied. This showed that five corpora per ovary or ten per ovulation represented the average. The animals from which data were secured concerning the number of eggs or corpora were treated in every respect as to food, cage space, etc., identically with the animals in which the number of litter young was recorded. They were also in many cases litter mates of such animals. Evidently, then, under these conditions nine or ten ova are represented by only six or seven offspring carried to term.

27. On the production of the condition of 'pseudopregnancy' by infertile coitus or mechanical stimulation of the cervical canal in the rat. JosePH A. LoNG and Herbert M. Evans, University of California.

We have previously shown that the advent of the next oestrus is delayed when the rat is allowed to mate with a vasectomized male or when the cervical canal is stimulated by the momentary insertion of a small glass rod. This pause, which we have proved to result from delayed ovulation, may be due either to some sort of direct repression of follicular growth or to a continuance of life of the corpora lutea which in the case of cattle have apparently been shown to hold off follicular growth and oestrus. The corpora lutea in these cases come to resemble those of pregnancy. As we have previously explained, we are to understand this remarkable response as a contrivance to insure implantation. The fact that deciduoma are difficult to produce during normal oestrous cycles, but can be produced after cervical stimulation, is in strict harmony with the idea that changes are thereby provoked which facilitate implantation. We may suppose something has occurred to 'activate' the corpora lutea. The corpora are affected through humoral paths, since these phenomena all occur with the transplanted ovary. But nervous pathways are probably concerned in initiating the 
change, for the products of abrasion of the cervical mucosa do not themselves cause these changes (Freyer; see below). The designation 'pseudopregnancy' is justified on further grounds than because of the prolongation of life span of the corpora lutea. Most striking is a change in the character of the vaginal epithelial mucosa. In pregnancy the vaginal mucosa becomes a high stratified epithelium, but with its surface cells columnar instead of squamous in type. Furthermore there ensues a characteristic vacuolization of its middle cell layers, a phenomenon beginning about the tenth day of gestation and reaching its greatest expression on the sixteenth day. These changes are inaugurated in the vaginal mucosa ten or more days after mechanical stimulation of the cervical canal.

28. On the cause of the effects produced by stimulation of the cervical canal in the rat. M. G. FreYer (introduced by H. M. Evans), University of California.

The delay in the appearance of the next oestrus and the condition of so-called pseudopregnancy produced by mechanical stimulation of the cervical canal in the rat has been shown by Long and Evans to take place in animals in which ovarian transplantation has recently been carried out. We can, hence, not refer this effect to the nervous connections of the ovary itself. It seemed possible that the slight injury to the cervical epithelium might lead to hormonal products which when absorbed and reaching the circulation thus affect the ovary directly or indirectly by means of some other endocrine gland.

At the suggestion of Doctors Evans and Long, six careful experiments were carried out in order to test this point. Epithelial scrapings were made from the lower portions of the cervical canal of six animals which were in the pro-oestrous period or at the transition between pro-oestrus and oestrus. This material, obtained under aseptic precautions, was immediately injected into the perito-. neal cavity of six other animals which happened to be at the same stage of the oestrous cycle. The succeeding oestrous cycles in the recipient animals were of normal duration. None of the characteristic effects of cervical stimulation were obtained. It would hence appear that the initial part of this mechanism is actually mediated by nerve impulses which, however, produce humoral changes so that the corpora lutea of recently transplanted ovaries, which can only be reached by the blood stream, are in some way invigorated and continued in function.

29. A characteristic histology of the vaginal mucosa during lactation. JoSEPH A. Long and Herbert M. Evans, University of California.

During lactation the vaginal smear in the rat resembles closely the picture found during the dioestrous interval of the normal oestrous cycle, i.e., it consists of polymorphonuclear leucocytes and a variable content of irregularly sized epithelial cells. Nevertheless, the histology of the vaginal mucosa at this time differs widely from that found in the dioestrous pause. We have previously established the fact that ovulation does not occur during lactation. Ovulation is always heralded by characteristic changes in the structure of the vaginal mucosa and also in the vaginal smear. In both pregnancy and lactation ovarian function is manifested by actively secreting corpora lutea which in turn may be viewed as repressing all follicular growth and activity. We have shown in the preceding 
section that a characteristic vaginal histology occurs throughout gestation. It is also a fact that during gestation the vaginal smear resembles that of the normal dioestrous pause. Similarly during lactation characteristic changes occur in the vaginal mucosal histology without changes in the smear. The epithelium in one respect resembles that found in pregnancy in that it possesses a surface layer of cylindrical cells. But the gravid vaginal mucosa is high, that of lactation low. While on the second day of suckling this mucous membrane may consist of four or five cell layers, by the fourth day more than three layers are seldom encountered, and on the sixteenth day, when lactation may be assumed to be at its height, most of the mucosa consists of but two cell layers, the superficial of which is constituted by cubical or low cylindrical elements. The strict dependence of this characteristic epithelium upon the performance of the mammary glands, which divert and limit ovarian function to the corpora lutea, is illustrated in the most striking way when the young are removed. Within forty-eight hours after removal of the young the low columnar mucosa of lactation gives place to a high, stratified squamous epithelium.

.30. On the production of deciduomata during lactation. JosePH A. LoNg and HERBert M. Evans, University of California.

Our preliminary experiments seemed to indicate that deciduoma were not easily produced by the contact of foreign bodies with the uterine mucosa during lactation. We were consequently under the impression that the rarity of conception during lactation might be referable to an unfavorable implantation reaction in some way associated with lactation. We have continued our operations upon the uterus during lactation. Typical deciduomata can be produced when the procedure is carried out at any time after the fourth day of lactation and the animal sacrificed one week after the operation. It is consequently necessary to refer the well-known comparative immunity from a second gestation which characterizes the early period of lactation in all animals, to the lack of ovarian changes associated with both heat and ovulation, not to difficulties in implantation of ova. The existence of a vigorous deciduoma reaction during lactation when uterine atrophy normally occurs would appear to establish conclusively the relation of this response to the existence of functional corpora lutea, for in all conditions in which functional corpora are present the response can be elicited.

31. Cyclic changes in the mammary gland of the rat associated with the oestrous cycle. Monroe Sutrer (introduced by H. M. Evans), University of California.

The exact mechanism responsible for the assumption of function on the part of the mammary gland has received a considerable amount of attention during the last few years. Although an indirect nervous connection between mammae and uterus exists (influence of suckling on uterine contractions), it has been generally assumed that the development of the mammary apparatus is due to hormonal influences. As is well known, these hormones have been variously supposed to come from corpus luteum, placenta, or foetus. I have been encouraged by Doctors Evans and Long to study the changes which may be observed. 
in the mammary glands of virgin female rats at various steps in the oestrous cycle. The study of sections was eventually abandoned and gross mounts were made of spreads of the entire glands which had been stained and cleared.

The following conditions have been detected: Toward the end of the prooestrous stage (stage 0 of Long and Evans) the mammary tree exhibits long, slender branches which have a few almost naked twigs projecting from them. Close inspection reveals that there are many minute bud-like processes on the twigs and on the main branches at infrequent intervals. In the next stage, oestrus (stage 1 of Long and Evans), when cornified epithelial cells are found in the vaginal smear, undoubted evidence occurs of pronounced growth in the mammary tree. The small buds on the mammary twigs have sprouted out to varying degrees and new ones have appeared. Instead of appearing generally smooth and naked, the branches and twigs are irregular and covered with numerous projecting buds. The size and shape of the branches vary greatly from branch to branch and in a given branch. This great variability appears to be one of the most marked characteristics of rapid growth. By the time leucocytes have appeared in the vaginal smear, evidences of further growth in the mammary tree can be seen in the increasing complexity of the secondary branches. By this time we know that ovulation has normally occurred and young corpora lutea have been formed. The end branchings of the mammary tree often form transparent bulb-like projections which vary greatly in shape and size. This complexity of the tree and some slower growth of it undoubtedly continue until near the nest pro-oestrous stage when, possibly due to degeneration of the corpora lutea, regression occurs.

There is thus a regular cycle of growth changes imposed upon the mammary ducts, and although these are undoubtedly accelerated and are maintained by the corpora lutea, they may be detected and are quite marked before the corpora are formed.

92. On the rapid maturation of the ovary by transplantation of the youthful gonad to adults. Joseph A. Long and Herbert M. Evans, University of California.

In order to determine whether we could produce an experimental precocity in the development of the remainder of the reproductive system, we attempted to transplant adult ovaries into young animals. As a matter of fact, an exchange of ovaries was carried out between immature animals from twenty to thirty days of age and adults between five and six months of age. The adult grafts succumbed, but in every instance the immature ovaries were vascularized and grew rapidly, although these also in some instances did not continue to function. It is, however, remarkable that in all instances at least one set of Graafian follicles and corpora lutea were produced by the infantile ovaries in adult hosts. Furthermore, these changes took place in from six to eight days and brought on typical oestrus of the adult host as seen by changes in the vaginal smear, behavior, etc. It is apparent that endocrine influences of the adult tissues are responsible for provoking this sudden maturation of the sex gland, which normally occurs from one to two months later. 
35. The method of opening of the vagina in the rat. K. O. HALDEMAN (introduced by H. M. Evans), University of California.

At birth the lumen of the vagina extends caudal to within $1.2 \mathrm{~mm}$. of the.external surface of the body. The structure closing the vagina consists of a solid, branching core of stratified squamous epithelium surrounded by compact connective tissue. This condition persists until, at about the age of thirty to forty days, several centers of cornification appear in this epithelial core and vesicles containing desquamated cornified material and leucocytes are formed. The vesicles enlarge and coalesce so as to form a lumen through the epithelial core. The first external sign of impending opening is a turgescence and wrinkling of the future lips of the vagina. Occasionally a median cord extends dorsoventrally across the vaginal orifice for several days after opening. Frequently a plug of cornified material protrudes from the opening soon after it is established. Sections through the vaginae prior to their opening in animals older than thirty days showed large masses of cornified material, non-cornified cells, and leucocytes in the lumen near its distal end. In some cases small areas of the vaginal mucosa were covered with cornified epithelium. Five cases were studied to determine whether or not ovulation had occurred, and in no instance was this a fact. These isolated patches of epithelial cornification must not be confused with the complete cornified transformation of the vaginal mucosa accompanying oestrus.

34. On the association of continued cornification of the vaginal mucosa with the presence of large vesicles in the ovary and the absence of corpus formation. HERBert M. Evans and Joseph A. Long, University of California.

It has already been shown that in the normal oestrous cycle of the rat cornification changes in the vaginal mucosa are associated with the enlargement and maturation of follicles and that these changes cease at about the time of ovulation. Normally the cornified stage lasts about thirty hours.

As a rare anomaly (seven cases in about 800 rats) cornification of the vaginal mucosa may be greatly prolonged; instances of $2,3,5,7,11,11$, and even 21 days have been observed. In one case in which cornification had persisted for five days and in two cases of eleven days the animals were tested and oestrus found to be still present. All of the seven rats were killed while this phenomenon was still in progress, and the ovaries examined in serial section. The most striking thing about them was the presence of large, fluid-filled vesicles, many of these possessing a thick, apparently healthy granulosa layer which together with the basement membrane is invaginated at many points by blood-vessels and containing what appeared to be normal eggs. Others were clearly undergoing degeneration, leading to the formation of large, thin-walled vesicles devoid of ova. In addition, the ovaries were notable by reason of the absence of normal healthy corpora lutea, those present being apparently in process of degeneration-quite markedly so in the one case of twenty-one days.

We have observed similar long cornified stages in the vaginal smears of two cases in which the ovaries were transplanted to the rectus muscle and in which also the ovarian findings resembled the above. This fact would appear to support convincingly the idea that these ovarian changes produce their effects on the vagina through humoral rather than nervous pathways. 
(Experiments on the endocrine relations of the ovary in the rat include abstracts 35 to. 38.)

35. The effect of thyroid feeding on the oestrous cycle of the rat. HERBERT M. Evans and Joseph A. Long, University of California.

Thyroid obtained daily from freshly slaughtered beeves was fed in doses varying from $\frac{x}{4}$ gram to an entire half gland. The rats used for feeding as also those for controls were selected from a large stock because they exhibited approximately regular four-day cycles.

In all cases thyroid feeding was accompanied by an increased consumption of food, but decrease in body weight. On the one hand, when the doses were larger ( $\frac{1}{4}$ to $\frac{1}{2}$ gland) loss in body weight was pronounced and some animals succumbed, the cycle being greatly lengthened or inhibited altogether. On the other hand, when the doses varied from $\frac{1}{4}$ to $1 \frac{1}{2}$ grams daily, amounts also sufficient to produce loss of weight with increased consumption of food, the oestrous cycles were usually not greatly disturbed. There consequently do not appear to be specific effects of thyroid substance on the oestrous cycle.

36. The effect of thyroidectomy on the oestrous cycle of the rat. HeRBert M. Evans and Joseph A. LoNG, University of California.

Both thyroids were removed from three groups of rats which lived a long postoperative life: thirty-one adults, seventeen young rats 37 to 54 days of age, and eleven suckling ones. In all cases there was no doubt but that by far the largest part of the thyroid was excised, and in the youngest rats the operation was performed under binocular microscopes. The mortality from the operation is low. In the case of the adults the operation was usually followed by a pause in the oestrous cycles of 6 to 27 days, but in turn succeeded by normal oestrous cycles, about twenty of which were observed.

The operations on both the young and suckling animals influenced appreciably neither the time of maturity nor the lengths of oestrous cycles. Several of the second group after reaching an age of several months were autopsied and found to possess what appeared to be lobes of regenerated thyroid tissue in many cases almost of the size of normal glands. Sections found these to be thyroids which had regenerated in spite of the effort which had been taken to secure complete ablation.

37. The effect of feeding the anterior lobe of the hypophysis on the oestrous cycle of the rat. Herbert M. Evans and Joseph A. LoNg, University of California.

Four sets of experiments were carried on, in two of which fresh glands were fed and in two dried hypophysis from Armour \& Co. and from Parke-Davis \& Co. In all cases the feeding was begun at weaning, on the twenty-first to twenty-third day, litter mates being used as controls. Daily observations were made to determine the opening of the vagina and cyclical changes in the vaginal smear. A total of fifty-five rats was used for the experiments and fifty-four for controls.

The anterior lobes were dissected from the glands of freshly slaughtered cattle and were ground, weighed, and fed within six hours of slaughtering. A half gram was given each rat, which had been isolated in a clean metal box where it could be seen that the total amount given was consumed, after which the animal 
was returned to its cage and given ordinary food. In one set the controls were not fed differently from their mates except for the hypophysis; but in the other set the controls were given in addition $\frac{1}{2}$ gram of raw liver daily to offset the possible nutritive value of the fresh hypophysis. Each rat was weighed at intervals of four days. In both sets the hypophysis-fed animals and controls showed neither significant differences in growth nor in the age of maturity and lengths of subsequent oestrous cycles. In the case of ten adult rats the total food intake was limited to 6 to 10 grams of the fresh anterior lobe and rolled barley. Their oestrous cycles (ten to twenty of which were observed) were not sensibly altered.

Similar tests were conducted with the dried commercial substance, except that no controls were given fresh liver. But for the fact that large doses could not be given without producing intestinal disturbances, the results were not substantially different from those given above.

38. The effect of the anterior lobe administered intraperitoneally upon growth, maturity, and oestrous cycles of the rat. 'Herbert M. Evans and Josepi A. LoNG, University of California.

The anterior lobes were dissected from fresh glands, were immersed five minutes in 30 per cent alcohol, rinsed thoroughly in sterile Locke's solution, triturated with a small amount of sand, and centrifuged for about half an hour, care being taken to carry out all manipulations aseptically. The supernatant fluid from centrifuging was injected into the peritoneal cavity in amounts from $\frac{1}{8}$ to $1 \mathrm{cc}$, , according to the age of the rat, the first dose being given at an age of about fourteen days. At the beginning a similarly obtained fluid substance from liver was given some controls, but soon discontinued because of its toxic effect. Every animal was weighed at intervals. of five days, beginning with the twentieth day of age. To date daily observations have been carried to the eightieth day. The subjoined table shows a greater rate of growth of the experimental animals as compared with their controls, a disparity which is increasing.

At the same time the effect of the anterior lobe has been to repress sexual development by delaying sexual maturity and lengthening the oestous cycles, in some cases oestrus being entirely inhibited.

In the case of five adult rats with previously regular four-day cycles, doses of 1 to 2 cc. of the anterior lobe fluid substance caused an immediate cessation of the four-day rhythm, the smaller doses permitting oestrus to recur at longer intervals, the larger inhibiting it altogether. These results are in marked contrast to the lack of effect produced by oral administration of the anterior hypophysis. As far as the influence on sex function is concerned, they are in marked contrast to prevalent opinion.

(See table on page 10) 


\begin{tabular}{|c|c|c|}
\hline$\Delta G \mathbb{D}$ & 38 EXPERIMENTAL ANIULLS & 38 LTYER MATE CONTROLS \\
\hline days & grams & grams \\
\hline 14 & 20.2 & 19.02 \\
\hline 20 & 31.6 & 33.14 \\
\hline 25 & 48.6 & 46.2 \\
\hline 30 & 61.7 & 60.0 \\
\hline 35 & 80.6 & 70.7 \\
\hline 40 & 95.6 & 86.2 \\
\hline 45 & 117.6 & 109.0 \\
\hline 50 & 140.8 & 126.1 \\
\hline 55 & 159.5 & 139.25 \\
\hline 60 & $\mathbf{1 7 7 . 0}$ & 153.3 \\
\hline 65 & 197.2 & 165.6 \\
\hline 70 & 214.5 & 173.7 \\
\hline 75 & 227.8 & 183.5 \\
\hline
\end{tabular}

